\title{
Herzog vindicated: Integrative taxonomy reveals that Trichosto- mum brachydontium (Pottiaceae, Bryophyta) comprises several species
}

\author{
Rosa M. Ros ${ }^{1}$, Olaf Werner ${ }^{1}$ and Ron D. Porley 2,* \\ 1 Universidad de Murcia, Facultad de Biología, Departamento de Biología Vegetal, Campus de Espinardo, \\ 30100-Murcia, Spain; rmros@um.es, werner@um.es \\ 2 Cerca dos Pomares, CxP 409M, 8670-052 Aljezur, Portugal; ron.porley@sapo.pt \\ * Correspondence: ron.porley@sapo.pt
}

\begin{abstract}
The morphologically variable moss Trichostomum brachydontium is very common in south and west Europe, particularly under Mediterranean and Atlantic climates. A morphological study was conducted alongside a molecular phylogenetic study based on $\mathrm{nr}$ ITS and cp $r b c L$ regions in order to assess if T. brachydontium is an exceptionally polymorphic species as evidenced by the number of described infraspecific taxa from the last century or, alternatively, if it includes more than one species, and if so, to find the valid name for them. Phylogenetic analyses of both nuclear and chloroplast datasets show that there are four well-supported clades. While the ITS based tree is in good agreement with the morphological data, there are a few inconsistencies with reference to the $r b c L$ tree; this may be explained by incomplete lineage sorting or by hybridization. The morphological survey revealed well-defined discriminate differences between the four phylogenetic lineages. The taxonomic conclusions include the recognition of four species: T. brachydontium s.s., T. herzogii (a new name proposed for var. cuspidatum), T. littorale and T. meridionale (a new name proposed for var. densum). Lectotypes are designated for T. brachydontium and T. littorale. Our results underline the ongoing need of integrative studies to examine further the underestimated diversity of the $T$. brachydontium complex in other regions.
\end{abstract}

Keywords: $c p-r b c L$; nr-ITS region; biodiversity; distribution; Mediterranean-Atlantic Europe; mosses; nomenclature; taxonomy; Trichostomum herzogii nom. nov., Trichostomum meridionale sp. nov

\section{Introduction}

The morphologically variable moss Trichostomum brachydontium Bruch is a very common plant of arid, exposed sites in the Mediterranean macrobioclimate, but it occurs equally in moist, sheltered biomes in oceanic and hyperoceanic (Atlantic) zones; furthermore, this Submediterranean-Subatlantic moss [1] occupies a wide range of niches. It has a worldwide cosmopolitan distribution, absent only in Antarctica. It occurs in North, Central and South America, Eurasia, Africa, Atlantic Islands, Indian Ocean Islands, Pacific Islands (New Zealand) and Australia [2]. In the Iberian Peninsula it is present in the majority of provinces of [3], though it is most characteristic of coastal and lowland districts (generally lacking on the Iberian Central Range), whereas in Britain and Ireland it has a western or Atlantic tendency [1].

Since the publication of T. brachydontium Bruch [4] a large number of subspecies, varieties and forms have been described. Herzog [5] took a special interest in the forms of $T$. brachydontium (T. mutabile Bruch nom. illeg.) during a trip he made to Sardinia in 1904. As well as his own extensive collections of T. brachydontium, he had access to collections from other contemporary bryologists to study the various forms known in Europe and Macaronesia (and beyond). He established four ideal types (densum, littorale, mutabile and cuspidatum), with four subtypes within mutabile (normale, cylindricum, cophocarpum and longirostre), and a further five forms that he considered as intermediate between the four ideal 
types. The work of Herzog is still relevant to this day and indeed to our study, and is an early example exploring phylogenetic relationships.

The four Herzog types have been considered in later floras and taxonomical works worlwide mostly as subspecies or other taxa of T. brachydontium, not withstanding that Herzog very clearly characterized them morphologically. In Guerra [3] four varieties of $T$. brachydontium are briefly mentioned for the Iberian Peninsula (var. cophocarpum (Schimp.) Cout.; var. cuspidatum (Braithw.) L.I. Savicz.); var. cylindricum (Schimp.) Cout.; and var. littorale (Mitt.) C.E.O. Jensen), while a further variety (var. unguiculatum (H. Philib.) Corb. \& Jahand.) is more or less dismissed as falling within the range of variation of the type. Rungby [6] and Koppe [7] reported the var. densum (Bruch \& Schimp.) Düll for Spanish areas and the last author proposed the subsp. pusillum F. Koppe based on material collected in the Balearic Islands. In earlier years additional varieties were described, for example var. robustum (Renauld \& Cardot) During and var. nigroviride (Renauld \& Cardot) Luisier, both from the Canary Islands [8], and from Madeira a form of T. brachydontium was reported as a new species, T. contortum (Kunze) Sérgio $[9,10]$, though this remains uncertain and has not been accepted in later checklists of European and Mediterranean mosses [11-13]. In other Mediterranean areas var. angustifolium (Lindb.) Wijk \& Margad. and T. mutabile var. brevifolium Schiffn. were also reported [12]. In Britain, bryological floras [14-18] state that two taxa have been recorded (var. littorale (Mitt.) C. Jens. (considered at species level by Braithwaite [14] and var. cophocarpum (Schimp.) P. Cout.). Nevetheless, Smith [18] stated that they intergrade with the type to such an extent that they cannot be maintained. As a result, most of these forms of T. brachydontium are now overlooked in most worldwide floras. This tendency towards taxonomic lumping may have the unintentional and indeed undesirable consequence of dismissing morphologically distinct taxa and ensuing recognition and reinstatement may require a revision of the species circumscription [19].

The first two authors of the present study have been using both morphometric and molecular techniques to study the Pottiaceae family and more specifically the subfamily Trichostomoideae [20-25] for many years, and most recently investigating forms of $T$. brachydontium from SE Spain. Moreover, the third author made many collections of $T$. brachydontium, mostly from Serra de Monchique in Algarve, Portugal, and recognized the wide variation therein. The present study does not attempt to address the full degree of variation shown by $T$. brachydontium across its entire distributional range - this would require looking at many more collections as well as from different geographical regions but to analyse the morphological variation of the species from a fresh perspective, using mostly Mediterranean and Atlantic samples and employing an integrative methodology. In this work, a morphological and molecular phylogenetic study was performed with the following objectives: 1 ) to assess if $T$. brachydontium is an exceptionally polymorphic species as evidenced by the number of described forms from the last century or if it includes more than one species, 2) to establish whether the morphotypes detected in T. brachydontium s.l. are genetically supported and 3) in the case that molecular data supports the existence of more than one species within T. brachydontium s.l., to find the valid name for them.

\section{Materials and Methods}

\subsection{Plant Material}

A total of 37 Trichostomum samples were used for the molecular study. One sequence was taken from GenBank and the other sequences were generated for this work from recent specimens mainly collected by the authors. Other bryologists (mentioned in the Acknowledgements section) also contributed material from Mediterranean and Atlantic zones. A group of species of the genera Oxystegus (Limpr.) Hilp. and Tortella (Müll. Hal.) Limpr. was used as outgroup for the ITS tree, and Barbula unguiculata Hedw., Tortella flavovirens (Bruch) Broth. and T. inclinata (R. Hedw.) Limpr. for the $r b c L$ tree, the sequences 
of which were also generated for this work. In addition, 58 samples were used for the morphological study only, as they could not be sequenced (Appendix A). The type specimens of most of the taxa considered in this work were studied (T. brachydontium, T. brachydontium var. cophocarpum, T. brachydontium var. cuspidatum, T. brachydontium var. cylindricum, T. brachydontium var. unguiculatum, T. littorale Mitt.) obtained from GLM, GOET, H, JE and NY herbaria.

\subsection{DNA sequencing}

DNA was extracted according to the $\mathrm{NaOH}$ protocol of Werner et al. [26]. The nr-ITS region was amplified with the primers ITS1 and ITS4 [27], and a fragment of the cp-rbcL gene was amplified with the primers $r b c L a-F$ [28] and $r b c L a-r e v$ [29]. All primers were used at a final concentration of $0.4 \mathrm{mM}$ and $2 \mu \mathrm{l}$ of stock DNA was used as a template in $25 \mu \mathrm{l}$ reaction volume with the Phire Plant Direct PCR Master Mix (Thermo Scientific, Spain). The amplification conditions were as follows: $3 \mathrm{~min}$ at $98^{\circ} \mathrm{C}, 35$ cycles with $5 \mathrm{~s}$ at $98^{\circ} \mathrm{C}, 30$ $\mathrm{s}$ at $55^{\circ} \mathrm{C}$ and $30 \mathrm{~s}$ at $72{ }^{\circ} \mathrm{C}$, and a final 5 -min extension step at $72^{\circ} \mathrm{C}$. Amplification products were controlled on $1 \%$ agarose gels and successful reactions were cleaned by adding $1 \mathrm{u}$ FastAP (Thermo Fischer) and $10 \mathrm{u}$ ExoI (ThermoFischer) for one hour at $37^{\circ} \mathrm{C}$ followed by a thermal inactivation of $15 \mathrm{~min}$ at $85^{\circ} \mathrm{C}$. Cycle sequencing was performed by the Central labs of the University of Murcia using the amplification primers.

\subsection{Data analysis}

The sequences were edited using Bioedit 5.0.9 [30] and aligned manually. Between taxa mean distances and within taxa mean distances were calculated with MEGA X [31]. We used the programm gappy [32] in order to identify reliable indels and recodify the indels in the data matrix as 0/1 character states. The TCS module of T-Coffee [33] was used to identify regions in the ITS alignment with low local reliability which were excluded from further analyses. The data were analyzed by Bayesian inference implemented with MrBayes 3.2 [34-36]. Gaps were treated as standard data. Trees were sampled across the substitution model space in Bayesian MCMC analysis itself [37] using the option nst=mixed. Therefore a priori model testing was not necessary. Indels were treated as separate unlinked partitions, using the restriction site model (F81). Two runs with four chains were conducted with 15,000,000 generations in the case of ITS, and 5,000,000 in the case of $r b c L$. Trees were sampled every 1,000 th generation and the first $1,000,000$ generations were discarded (burn-in) in order to exclude the trees before the chain reached the stationary phase. We checked for stationarity of the log likelihood values, that the Potential Scale Reduction Factor (PSRF) was close to " 1 " $(0.99<$ PSRF $<1.01)$, and that the estimated sample size was above 200. The final trees were edited with TreeGraph2 [38].

\subsection{Morphological study}

Standard microscopic observations were applied to study the plants of the clades revealed in the molecular analysis. Material was photographed using a light microscope (Leica DM1000 LED) with a micrometer inserted in an ocular and in a stereomicroscope (Leica A8APO) with a video camera connected (Leica camera: DFC295) in order to transfer the images to a computer. The Leica Application Suite, Version 4.1.0 was used for image analysis.

The plant material was critically studied, mindful of the four ideal types proposed by Herzog [5] and based mainly on the following character traits: size and colour of plants, growth form, stems comose or not, position of leaves when dry and moist, shape and size of leaves, apex of leaves, leaf lamina, margins incurved or not, teeth development in the basal part of lamina, colour and wall thickness of basal cells, length of the excurrent costa. 
If sporophytes were present, length of seta, size, shape and colour of the capsule, operculum beak length, peristome development and spores were also scored.

\section{Results}

\subsection{Molecular data}

We first used an ITS tree with several outgroup species belonging to the genera Oxystegus and Tortella to establish that Trichostomum crispulum Bruch can be considered an outgroup with respect to T. brachydontium s.l. (Figure 1a). Once this was confirmed we used a second alignment excluding the non-Trichostomum specimens to study with more detail the relationships within Trichostomum. This way, in the final alignment, fewer characters had to be excluded due to unreliable positions. The final ITS tree (Figure 1b) first separates an isolated sample from Austria. The remaining samples are divided in two sister clades. The first (0.92 pp) comprises T. brachydontium s.s. (1.0 pp) and T. meridionale (1.0 pp), the second T. littorale (1.0 pp), T. herzogii (1.0 pp) and an isolated sample from Greece close to T. herzogii (0.99 pp). The names given to the samples are in accordance with the combination of the molecular and morphological results (see taxonomic treatment). 

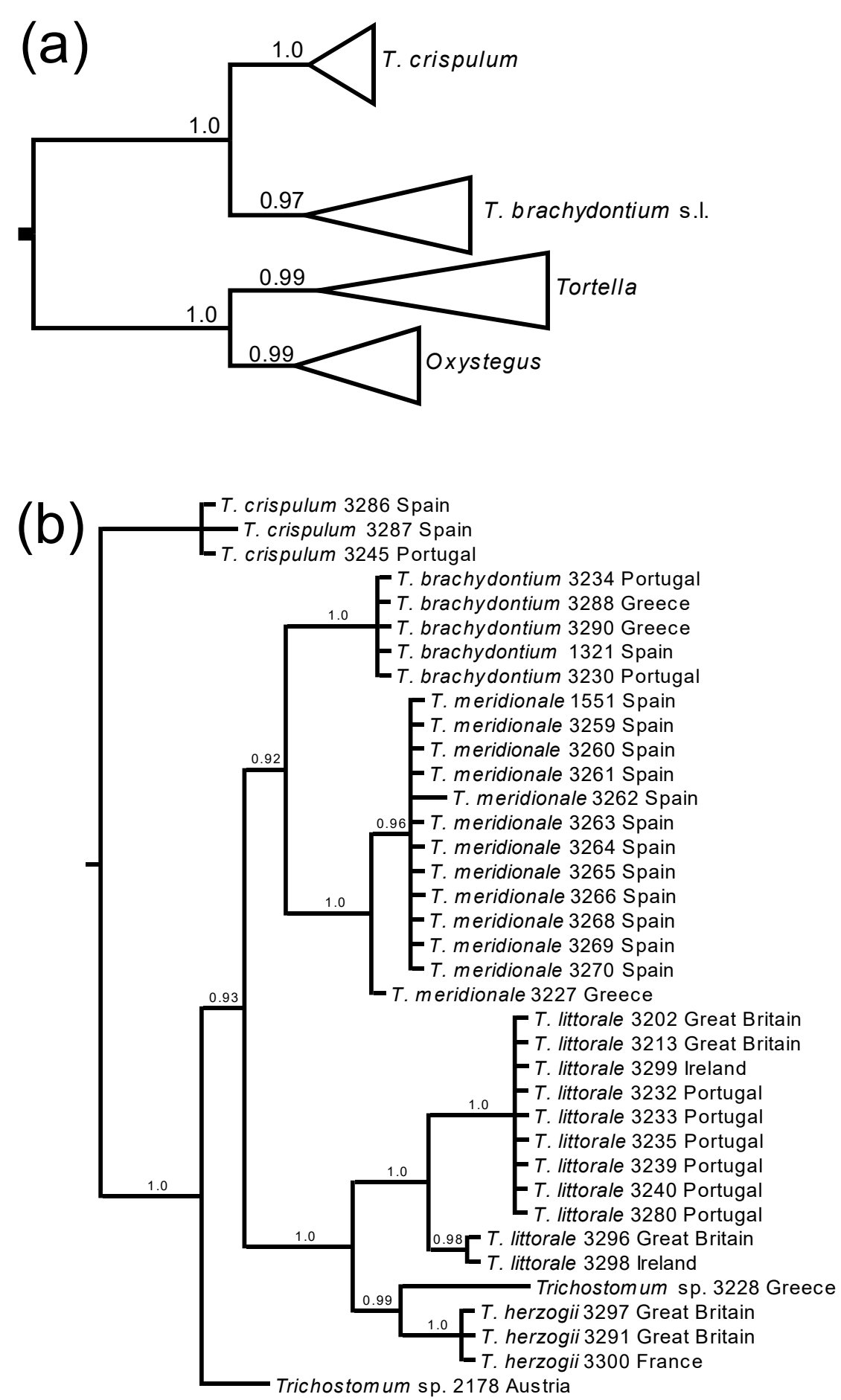

Figure 1. Phylogenetic relationships of Trichostomum based of ITS sequences. (a) Schematic overview of the phylogenetic relationships including outgroup. A group of species of the genera Oxystegus and Tortella was used as outgroup. Trichostomum brachydontium s.l. forms a monophyletic clade sister to T. crispulum; (b) Detailed view on the Trichostomum sequences reveals several well-supported clades within T. brachydontium s.l. which correspond to morphological descriptions (T. brachydontium s.s., T. meridionale, T. littorale and T. herzogii). Two samples within the T. littorale clade are slightly different from the majority of this clade. 
A look at the genetic distances based on ITS sequences (Table 1) shows that the within species mean distances are much lower than the between species values. The maximum within species distance at individual level was 4 in the case of T. littorale, and within T. brachydontium s.s. and T. herzogii all sequences were identical. The minimum between species distance was 6 between several samples of T. brachydontium s.s. and T. meridionale).

Table 1. Mean genetic distances between and within species based on ITS sequences. The within species differences are much lower than the between species distances.

\begin{tabular}{lccccccc}
\hline & 1 & 2 & 3 & 4 & 5 & 6 & 7 \\
\hline 1 T. crispulum & 0.67 & & & & & & \\
2 T. brachydontium & 12.3 & 0.0 & & & & & \\
3 T. littorale & 17.0 & 13.6 & 1.3 & & & & \\
4 T. herzogii & 16.3 & 11.0 & 8.6 & 0.0 & & & \\
5 T. meridionale & 11.3 & 7.0 & 13.6 & 12.0 & 0.3 & & - \\
6 Trichostomum sp. 2178 Austria & 10.3 & 8.0 & 11.6 & 11.0 & 7.0 & - & - \\
7 Trichostomum sp. 3228 Greece & 17.3 & 12.0 & 11.6 & 7.0 & 8.2 & 14.0 & - \\
\hline
\end{tabular}

In the case of the $r b c L$ sequences, the samples of T. crispulum shared a haplotype with three samples of T. brachydontium s.l. and the basal part of the rbcL tree is therefore not resolved (Figure 2). One of these samples, morphologically and based on the ITS sequences, belongs to T. brachydontium s.s., another to T. meridionale and the third is the isolated sample from Greece. The remaining samples are situated in well-supported clades, but the relationship among these clades remains unresolved. These clades largely confirm the species assignation based on morphology and the nuclear ITS sequences, except for one sample (T. brachydontium 3234 from Portugal) that according to ITS belongs to T. brachydontium s.s. and which here is placed with the T. littorale samples. The isolated sample from Austria is situated close to T. herzogii. 
Tortella inclinata 3247

\section{- Tortella flavovirens 3255}

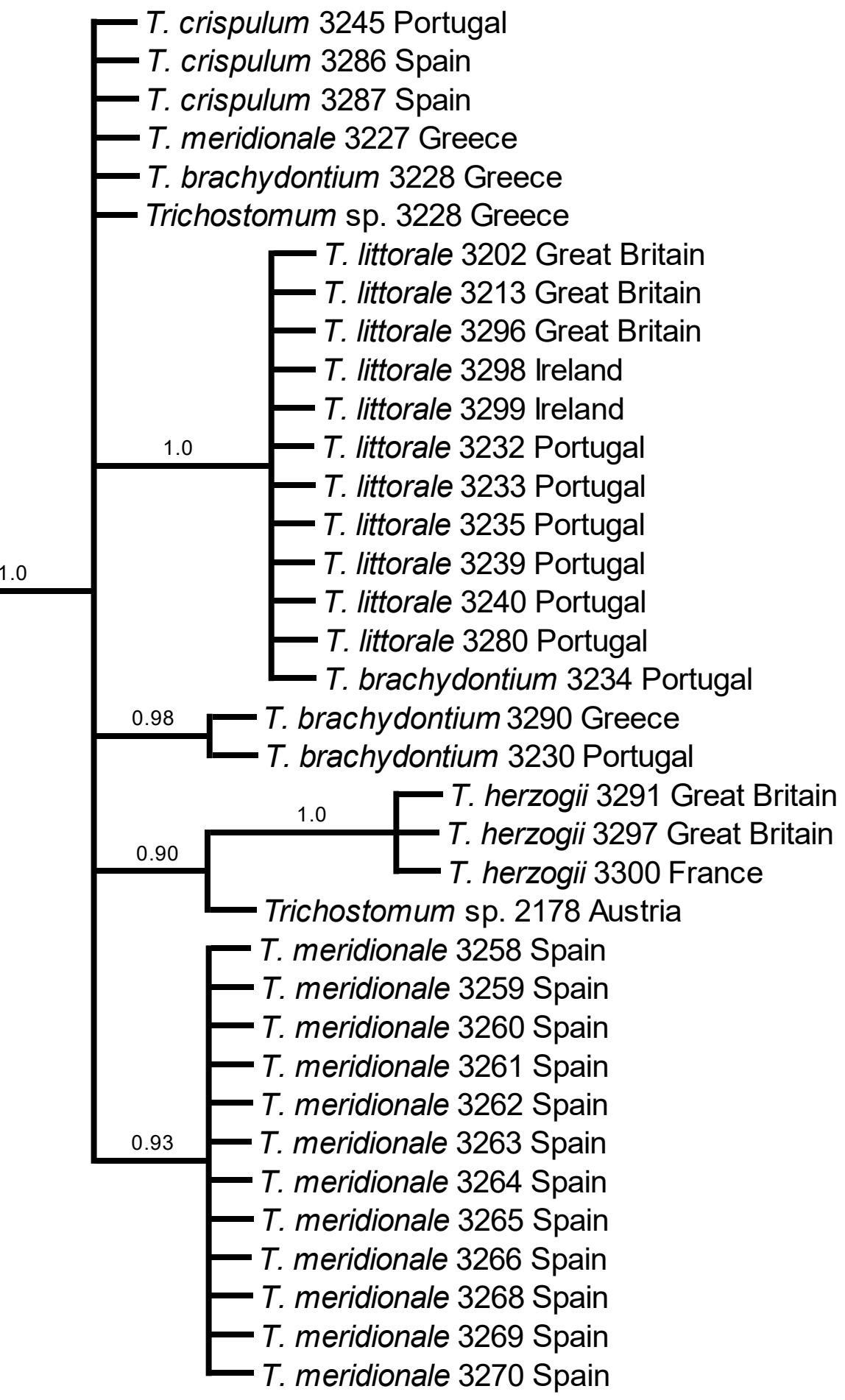

Figure 2. Phylogram based on $r b c L$ sequences. Three of the T. brachydontium s.l samples share their rbcL haplotype with the T. crispulum samples. The four resolved clades correspond mainly with the species defined based on morphology, except sample 3234, which shows T. brachydontium morphology but a T. littorale rbcL haplotype. The sample from Austria (Trichostomum sp. 2178) is placed near T. herzogii. 
The genetic distances calculated for the $r b c L$ gene fragment are generally much lower than those calculated for the ITS region (Table 2). The within species distances were 0 in the case of T. crispulum, T. herzogii, and T. littorale, and low $(0.15)$ in the case of T. meridionale. In the case of T. brachydontium, the within species distance (1.67) was higher than the between species distance of this species compared with most of the remaining species. This is due to the samples 3228 and 3234, which are clearly different from the two remaining $r b c L$ sequences we obtained for this species.

Table 2. Mean genetic distances between and within species based on $r b c L$ sequences. The within species differences are relatively high in T. brachydontium.

\begin{tabular}{lccccccc}
\hline & 1 & 2 & 3 & 4 & 5 & 6 & 7 \\
\hline 1 T. crispulum & 0.00 & & & & & & \\
2 T. brachydontium & 0.17 & 1.67 & & & & & \\
3 T. littorale & 2.00 & 1.17 & 0.00 & & & & \\
4 T. herzogii & 3.00 & 3.17 & 5.00 & 0.0 & & & \\
5 T. meridionale & 0.85 & 1.01 & 2.85 & 3.85 & 0.15 & & \\
6 Trichostomum sp. 2178 Austria & 1.0 & 1.17 & 3.00 & 2.00 & 1.85 & - & \\
7 Trichostomum sp. 3228 Greece & 0.00 & 0.17 & 2.00 & 3.00 & 0.85 & 1.00 & - \\
\hline
\end{tabular}

\subsection{Morphological study}

Plants from the four main clades correspond well to the four main morphotypes, based on characters used by Herzog [5] which were checked by the study of the type specimens: T. meridionale (densum type), T. littorale (littorale type), T. brachydontium s.s. (mutabile type), and T. herzogii (cuspidatum type).

The Austrian Trichostomum sp. sample 2178 shows morphological similarities with $T$. herzogii, and the Greek Trichostomum sp. sample 3228 with T. meridionale.

The main diagnostic characters that enable the separation of the four species are summarized in Table 3.

Table 3. Comparison of morphological traits among species of Trichostomum brachydontium complex. Differential characters are

Traits

Plants size

Colour of plants

Life- form

Stem tomentum

Stem ramification

Stem apex

Flagelliform shoots

Leaves when dry

Leaves when moist

Median and upper narrowly lingulate to leaf shape

T. brachydontium
$(0.7-) 1.0-2.0 \mathrm{~cm}$
bright green above,
brown below
tuft
present
distinctly interrupted

Sometimes distinctly comose

not seen

crispate

patent to spreading, apical leaves with the tips recurved

narrowly lanceolate or ensiform written in bold.

T. herzogii

(1.0)2.0-3.0(-5.0) cm

yellowish green above, reddish below

tuft

present

distinctly interrupted or not

\section{not distinctly comose}

occasional

incurved or crispate

erect to erect-patent, apical leaves spreading

linear-lanceolate

\section{T. littorale \\ $(0.5-) 1.5-3.0 \mathrm{~cm}$ \\ olive-green above, brown below \\ tuft/cushion \\ absent \\ distinctly interrupted}

distinctly comose

\section{frequent}

incurved or slightly

crispate

erect to erect- patent,

comal leaves spreading or with the tips re-

curved

lingulate, oblong-lingulate sometimes slightly lanceolate or spatulate
T. meridionale 0.3-0.5(-1.0) cm bright green above, yellow to brown below dense and short turf absent distinctly interrupted or not

distinctly comose

not seen

incurved

erect to erect- patent, comal leaves spreading

lingulate to spatulate, occasionally panduriform or lanceolate 


\begin{tabular}{|c|c|c|c|c|}
\hline $\begin{array}{l}\text { Median and upper } \\
\text { leaves size }\end{array}$ & $\begin{array}{c}(1.35-) 1.80-3.00(-3.80) x \\
0.30-0.50(-0.60) \mathrm{mm}\end{array}$ & $\begin{array}{l}(1.22-) 2.00-3.45(-3.61) \mathrm{x} \\
(0.21-) 0.35-0.50(-0.57) \\
\mathrm{mm}\end{array}$ & $\begin{array}{c}(0.60-) 1.00-1.90(-2.30) x \\
0.20-0.40(-0.50) \mathrm{mm}\end{array}$ & $\begin{array}{l}0.90-1.90(-2.30) \times \\
(0.20-) 0.30-0.50(-0.60) \\
\mathrm{mm}\end{array}$ \\
\hline Length/width ratio & $5.0-8.0$ & $5.0-7.6(-8.9)$ & $3.0-4.6(-6.6)$ & $3.4-4.0$ \\
\hline Lamina & $\begin{array}{l}\text { flat to slightly canalic- } \\
\text { ulate, twisted, undu- } \\
\text { late, unistratose, fragile }\end{array}$ & $\begin{array}{l}\text { strongly canaliculate, } \\
\text { not twisted, undulate } \\
\text { or not, rarely bistratose } \\
\text { in small patches be- } \\
\text { low, not fragile }\end{array}$ & $\begin{array}{l}\text { canaliculate, rarely flat, } \\
\text { not twisted, slightly un- } \\
\text { dulate, rarely bistratose } \\
\text { in small patches be- } \\
\text { low, not fragile }\end{array}$ & $\begin{array}{l}\text { flat to canaliculate, not } \\
\text { twisted, slightly undu- } \\
\text { late, unistratose, not } \\
\text { fragile }\end{array}$ \\
\hline Basal lamina colour & $\begin{array}{l}\text { yellowish or hyaline, } \\
\text { contrasting with upper } \\
\text { lamina }\end{array}$ & $\begin{array}{l}\text { reddish, concolorous } \\
\text { with upper lamina }\end{array}$ & $\begin{array}{l}\text { yellowish or hyaline, } \\
\text { contrasting with upper } \\
\text { lamina }\end{array}$ & $\begin{array}{l}\text { yellowish or hyaline, } \\
\text { contrasting with upper } \\
\text { lamina }\end{array}$ \\
\hline Leaf apex & $\begin{array}{l}\text { short-acuminate or } \\
\text { more rarely acute }\end{array}$ & $\begin{array}{l}\text { long-acuminate to su- } \\
\text { bulate }\end{array}$ & obtuse, mucronate & obtuse, mucronate \\
\hline Basal margin teeth & $\begin{array}{l}\text { absent or weakly devel- } \\
\text { oped }\end{array}$ & $\begin{array}{l}\text { absent or weakly devel- } \\
\text { oped }\end{array}$ & usually prominent & $\begin{array}{l}\text { absent or weakly devel- } \\
\text { oped }\end{array}$ \\
\hline Costa & $\begin{array}{l}\text { gradually narrowing } \\
\text { from base to apex }\end{array}$ & $\begin{array}{l}\text { gradually narrowing } \\
\text { from base to apex }\end{array}$ & $\begin{array}{l}\text { gradually narrowing } \\
\text { from base to apex }\end{array}$ & $\begin{array}{l}\text { gradually narrowing } \\
\text { from mid-leaf to apex }\end{array}$ \\
\hline $\begin{array}{l}\text { Length of excurrent } \\
\text { costa }\end{array}$ & $(50-) 90-150 \mu \mathrm{m}$ & $70-150 \mu \mathrm{m}$ & $20-85 \mu \mathrm{m}$ & $25-60 \mu \mathrm{m}$ \\
\hline $\begin{array}{l}\text { Basal lamina costa } \\
\text { cross-section }\end{array}$ & plane-convex & biconvex & plane-convex & plane-convex \\
\hline $\begin{array}{l}\text { Mid-basal and para- } \\
\text { costal basal cells }\end{array}$ & thin-walled & $\begin{array}{l}\text { usually thick-walled, } \\
\text { obscurely nodulose }\end{array}$ & $\begin{array}{l}\text { sometimes thick- } \\
\text { walled }\end{array}$ & thin-walled \\
\hline Sporophyte & 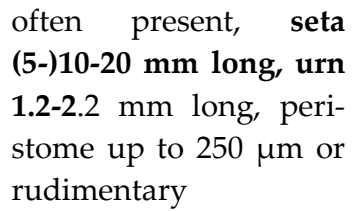 & not seen & not seen & $\begin{array}{l}\text { often present, seta } 5-10 \\
\text { mm long, urn 1.0-1.5 } \\
\text { mm long, peristome ab- } \\
\text { sent or rudimentary up } \\
\text { to } 55 \mu \mathrm{m}\end{array}$ \\
\hline
\end{tabular}

Within the T. brachydontium complex, the most notable feature of T. meridionale is its small size, consistent across both Spanish, Sardinian and Greek specimens available for study. The non-tomentose stems are no more than $1 \mathrm{~cm}$ tall, and form very short and dense turfs, not cushions, hardly standing proud of the substrate and easily detached from it. The shoots are green above, grading to yellow to brown below, and superficially resemble a small Weissia Hedw. with incurved leaf margins. In spite of their small size stems can be distinctly interrupted and are distinctly comose. When dry the leaves are incurved, when moist they are erect to erect-patent, only the comal leaves are spreading, and the leaves are small, no more than $2.30 \mathrm{~mm}$ long (with a low length/width ratio not exceeding 4.0). The leaf lamina is usually flat, often with incurved margins in the upper leaf, with an obtuse apex ending in a small mucro, 25-60 $\mu \mathrm{m}$ long. Leaf shape on the microscope slide is variable, but is typically lingulate, narrowly elliptical, spathulate to panduriforme (constricted at the point of transition between the smooth basal laminal cells and the papillose cells above). Marginal teeth in the lower third of the leaf are lacking or weakly developed. A useful character is the strong costa, remaining strong to about mid-leaf from where it gradually narrows to the apex. Sporophytes are usually always present, the ellipsoidal to cylindrical urn is up to $1.5 \mathrm{~mm}$ long, and when mature is yellow-reddish to brownish, and held on a yellow seta to $10 \mathrm{~mm}$ long. The peristome is rudimentary or absent.

Microscopically, T. littorale is easily separated from T. meridionale and other Trichostomum in the present study by possession of a few to several distinct teeth on the lower third margin at about the point where the smooth basal laminal cells merge into the papillose upper cells (transitional zone). The teeth are formed from an outgrowth of the transverse cell wall and may be slightly recurved or weakly bifurcate. In some specimens there may be leaves in which the teeth are weakly developed, but normally there will be some leaves that present distinct teeth; also the basal scale-like leaves are dentate from base to 
apex. In the field T. littorale is larger than T. meridionale, with stems up to $3 \mathrm{~cm}$, several times branched, with innovations at each point of branching, sometimes with flagelliform shoots, and distinctly comose, forming olive-green cushions or tufts. The leaves are small, reaching a maximal length of $1.90(-2.30) \mathrm{mm}$, and as in T. meridionale, they present a very short length/width ratio, typically 3.0-4.6, although in some samples the ratio can attain 6.6. The lamina is usually canaliculate and bistratose in small patches below, both features shared only by T. herzogii. Some forms are recognizable in the field due to the comal leaves spreading, sometimes with the leaf tips recurved, and the mid-lower stem leaves erect to erecto-patent when moist with a slightly sheathing base, often undulate and strongly incurved when dry. Other useful characters include the leaf shape, lingulate to spatulate, occasionally panduriform, rarely lanceolate, often slightly narrowed at the base, and an obtuse and mucronate apex, occasionally unguiculate, with a short excurrent costa to 20$85 \mu \mathrm{m}$. Sporophytes were not seen, but only perichaetia, having the perichaetial leaves, in contrast to the vegetative leaves, acute apices.

Trichostomum brachydontium s.s. and T. herzogii are most easily differentiated from the former taxa by leaf shape, size and apex. Both species present longer leaves, reaching about $3 \mathrm{~mm}$, with length/width ratio greater than 5.0, an acuminate apex and a long excurrent costa. In T. brachydontium s.s. plants are medium-sized, not exceeding $2 \mathrm{~cm}$ tall, bright green above, brown below, with tomentose stems, clearly interrupted in ramifications and sometimes distinctly comose. Leaves are crispate when dry, erecto-patent to spreading when moist, sometimes with recurved tips to the apical leaves. Other distinguishing characters of the leaves include the narrowly lingulate to narrowly lanceolate or ensiform shape, with a short-acuminate apex, rarely acute, and flat or slightly canaliculate, twisted, undulate and fragile lamina. The excurrent costa typically reaches $90-150 \mu \mathrm{m}$, and the basal margin is entire or obscurely denticulate causing possible confusion with $\mathrm{T}$. littorale, but it is never as pronounced as in that species. Sporophytes are frequent and larger than in T. meridionale, with an ellipsoidal to cylindrical orange capsule up to $2.2 \mathrm{~mm}$ long on a straw-coloured seta up to $20 \mathrm{~mm}$ long, a rudimentary or well-developed peristome $(\leq 250 \mu \mathrm{m})$ usually present, and spores 13-20 $\mu \mathrm{m}$ diameter.

Trichostomum herzogii presents the largest plants observed in the complex, being typically 2-3 cm high, but reaching up to $5 \mathrm{~cm}$, and is the only species with a reddish colour below the stem apex. The stems are clearly tomentose, as in T. brachydontium s.s., ramified but not distinctly interrupted, nor comose, and sometimes with flagelliform shoots. The orientation of the leaves is particularly distinctive, being incurved to slightly crispate when dry, strongly crispate at the apex, whereas when moist they are erect to erecto-patent and stiff, sometimes with the apical leaves tending to spread. The leaves may also be longer than in T. brachydontium s.s. reaching up to $3.61 \mathrm{~mm}$ long, with a length/width ratio up to 7.6(-8.9). In accordance with its linear-lanceolate shape, the apex is sharply acuminate to subulate and the excurrent costa is approximately as long as in T. brachydontium s.s., reaching 70-140 $\mu \mathrm{m}$, and the basal margin is entire or obscurely denticulate. Distinguishing characters of the species include the clearly canaliculate lamina, the leaf base concolorous with the upper lamina, the bistratose lower lamina in small patches, the biconvex costa in cross-section in the lower leaf and the usually thick-walled, obscurely nodulose mid-basal and paracostal cells. Sporophytes were not observed.

\section{Discussion}

Morphologically T. brachydontium s.l. presents a very variable complex regarding most of its character states, an issue that has been an impediment to providing a satisfactory circumscription of the taxon. Leaf morphology including size, basal and laminal cell dimensions and margin attributes, taken in isolation, provide few unambiguous quantitative characters, and furthermore character states overlap within the group. The present molecular study has however elucidated the relationships within the T. brachydontium complex in the Mediterranean-Atlantic region of Europe, and we have shown that 
morphological characters, considered in combination, allow confident recognition of the four clades that signify distinct taxa at the species level. Therefore, our results support the original hypothesis that there is more than one species within the protean taxon T. brach$y$ dontium and indicates the necessity of searching for their valid names.

The molecular results show that there are four well-supported clades in both chloroplast and nuclear based trees. While the ITS based tree is in good agreement with the morphological data, there are a few inconsistencies with reference to the $r b c L$ tree. These affect especially samples assigned to T. brachydontium s.s., one of which has a haplotype shared with T. crispulum and the other shared with T. littorale. Gene trees and species trees are not necessarily congruent; these results can be explained by incomplete lineage sorting, by which "ancestral polymorphisms persist through several speciation events" [39]. Large effective population sizes and short phylogenetic branches (expressed in generations) favour incomplete lineage sorting [40]. Another possible explanation for incongruencies of gene trees and species trees is hybridization [39]. At this point we cannot decide which of the two mechanisms may explain the inconsistencies of the $r b c L$ tree with the ITS tree and the morphological data, but in any case, the ITS tree is in good accordance with the morphological data and only a minor fraction of the samples shows these problems.

Regarding the ITS data, the within species variation is clearly lower than the between species variation. In two of the species (T. brachydontium and T. herzogii) the within species variation of the ITS sequences is even 0 and in the case of $T$. littorale the two subclades are morphologically slightly different and the within subclade variability is 0 . Consequently, it is plausible to propose a different taxonomic status for the two subclades. Herzog [5] also detected intermediate forms between T. mutabile and T. littorale ideal types, that he named littorale $>$ mutabile and littorale $<$ mutabile depending on the greater proximity to one or another type. The subclade of T. littorale with samples coded 3296 from Great Britain and 3298 from Ireland can be assigned to these intermediate forms, having both narrowly lingulate to lanceolate leaves up to $2.3 \mathrm{~mm}$ long, an undulate and fragile lamina and an acuminate to acute leaf apex as in T. brachydontium s.s. The presence in sample 3296 of teeth moderately developed in the basal leaf margin and upper leaves patent position it closer to T. littorale, whereas the teeth weakly developed or absent and the upper leaves spreading in sample 3298 place it closer to T. brachydontium s.s. Therefore, the morphology of both these intermediate specimens raises the question of whether they are deserving of taxonomic rank. Furthermore, during our study we observed other ostensibly intermediate forms, an issue Herzog was all too conscious of. These forms were not amenable to sequencing so therefore we were unable to assign them to any particular clade or taxonomic rank, and the possibility of hybridization remains. That is the case of a Sardinian specimen in CAG herbarium, having very small plants as in T. meridionale but with basal margin clearly dentate as in T. littorale. A particular issue is regarding material named $T$. contortum from Madeira [10]. We examined four specimens (LISU 149232, 162400, 162405 and 162406) and although we concluded that they most likely represented T. brachydontium s.s., collection 162406 exhibited characters reminiscent of T. herzogii, particularly in the long linear-lanceolate, canaliculate erect leaves with an acuminate apex, but the basal areolation and lack of any red colouration suggests T. brachydontium. Unfortunately the material is too old to be sequenced.

Two isolated samples, one from Austria and the other from Greece, could not be matched with any of the four species recognized in the present study. The Austrian sample is morphologically similar to T. herzogii and comparison with $T$. herzogii types and the sequenced specimens reveals that the Austrian plant has shorter and less canaliculate leaves. However, being a single sample means it is not possible to draw any taxonomic conclusion. The Greek sample, though lacking sporophytes, shows a close gametophytic similarity to T. meridionale. At this point, it is not possible to assess which processes are causing this incongruence between genetic and morphological data or indeed if these two specimens potentially represent distinct species. Very likely the taxonomy of the T. brachydontium complex is much more complicated than we have been able to detect in the 
present study, as the data certainly suggests by the discovery of different genotypes in non-European specimens (unpubl.).

Based on the data presented in this work, the reports of T. brachydontium and its synonyms in Mediterranean-Atlantic Europe should be re-evaluated, allowing a more accurate picture of the present distribution of the four species recognized here. The records of var. densum and var. cuspidatum can be fairly confidently related to T. meridionale and $T$. herzogii respectively. Of particular concern is the need for a critical revision of the reports of var. cophocarpum in Britain, due to the confusion with var. cuspidatum. Herzog [5] (pp. 475,476 ) was already aware that both Braithwaite and Dixon made erroneous statements regarding var. cophocarpum. It is clear from the description of var. cophocarpum in Braithwaite [14] and in Dixon [16] (1954), that the morphology corresponds to var. cuspidatum. This error has been perpetuated in the British floras, where besides var. littorale, only var. cophocarpum is said to be present, even though Herzog [5] and Mönkemeyer [41] both reported the occurrence of var. cuspidatum in England.

Some members of the T. brachydontium complex can be confused with Weissia. However, the latter genus is autoecious and in a moist state the leaf margins are more strongly incurved or involute above than typically seen in Trichostomum. Some morphs of Tortella nitida (Bruch) Broth. may also be mistaken for Trichostomum, as this species is genetically and morphologically very variable $[42,25]$. In some specimens of Tortella nitida little indication is given of belonging to this genus because the characteristic hyaline $\mathrm{V}$-shape basal area is not clearly delimited, but it can usually be recognized by two to several rows of elongate, thin-walled, smooth hyaline cells ascending the leaf margins [42], albeit sometimes indistinct. Such a cell pattern can also be seen in the T. brachydontium complex, although it is usually not so distinctive. Husnot [43] states in his key T. brachydontium (sub mutabile) peristome teeth are smooth and in T. nitida papillose, but in JE 04008874 syntype of $T$. brachydontium s.s., as well as in other specimens studied in this present work, we have observed papillose peristome teeth, and also in T. meridionale. Herzog [5] was especially concerned about the distinction between T. brachydontium s.s. and T. nitida and concluded that the position of the papillae was critical (however, we were unable to corroborate his interpretation regarding position of papillae and suggest that it is not a satisfactory chararcter to differentiate between them). Schimper [44] maintains that T. nitida differs from $T$. brachydontium in the more robust stature, with longer and slightly wider leaves, more arched-involute when dry, with a thicker costa that presents a smooth shiny dorsal surface (hence the name), and a basal areolation that is less thin and shorter. Eckel [42] also contrasts both taxa, but as it is possible that T. brachydontium s.s was not used for the comparison, the results are difficult to apply. In our opinion T. nitida presents a more extensive zone of smooth hyaline, rectangular, thick-walled cells extending further up the leaf than in T. brachydontim s.s., and older leaves are often fragile and broken. When dry the upper leaves of the T. nitida complex are oriented in a characteristic way, either regularly incurved and facing towards the stem axis or, in some forms, the leaves are very strongly crisped to circinate. The presence of mature sporophytes however allows a clear separation, T. nitida having capsules erect to somewhat inclined, elongate peristome teeth ca. $0.5 \mathrm{~mm}$ long, and spores $9-10 \mu \mathrm{m}$ in diameter [42].

\section{Taxonomic Treatment}

In the present study, by combining molecular and morphological studies we confirm that $T$. brachydontium includes at least four clearly distinct taxa. Based on the present work we consider species rank to be the most suitable option.

\subsection{The List of Taxa}

An account of the four species within T. brachydontium s.l. accepted in the present work is given below. Information is provided regarding types, nomenclature, taxonomy and etymology, morphological descriptions, diagnostic characters for infra-specific taxa, pertinent observations on morphology and distribution and habitat. 
(1) Trichostomum brachydontium Bruch in F.A. Müll., Flora 12: 393, pl. 3. 1829 (Figures 3-4).

Type citation: "An einer feuchten Erdwand bei Spezzia und auf Hügeln unter Gebüsch bei Cagliari. März und April”. Lectotype (designated here): [Italy, Sardinia] Trichostomum brachydontium Bruch, In umbrosis ad terram prope Cagliari. Febr. U. I. Müller, JE 04008873!; Isolectotype: Trichostomum brachydontium Bruch, In umbrosis ad terram prope Cagliari. Febr. U. I. Müller, PC 0703925. Syntypes: [Italy, Sardinia] Trichostomum brachydontium Br, In umbrosis ad terram pr. Cagliari, Febr. F. Müller, JE 04008874!; [Italy] Trichostomum mutabile Br. Eur., Golfo di Spezzia, Muller 1828, BM000666185.

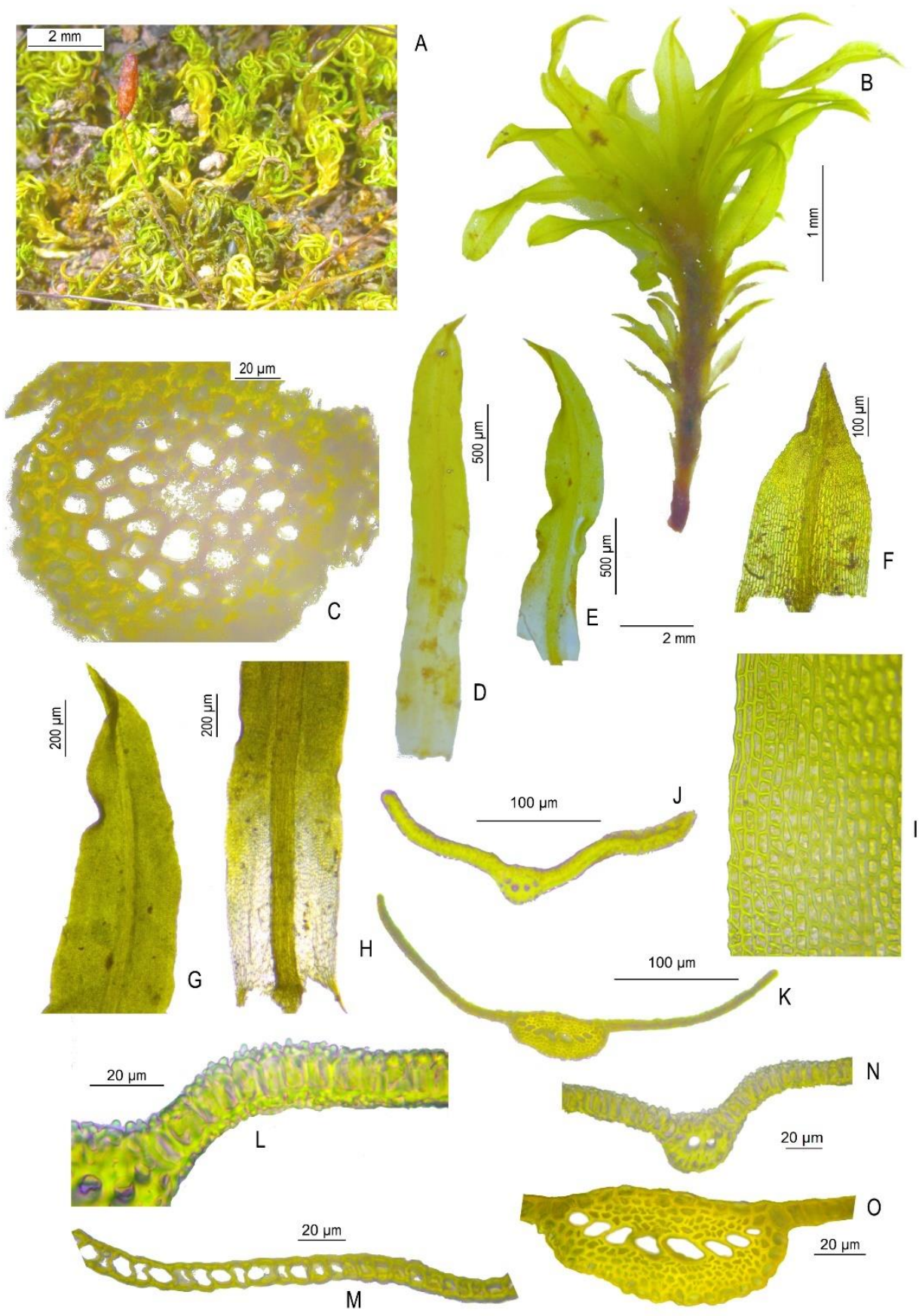


Figure 3. Macro- and microphotographs of gametophyte of Trichostomum brachydontium: (A) habit of fertile plants, (B) comose innovation, (C) stem cross-section, (D, E) apical and median leaves, (F) scale-like basal leaf, (G) upper part of leaf showing acuminate apex, $(\mathbf{H})$ hyaline basal part of leaf not expanded, contrasting with upper part (I) margin near base of lamina with weakly developed teeth, $(\mathbf{J})$ leaf cross-section in upper lamina, $(\mathbf{K})$ leaf cross-section in basal lamina, (L) upper lamina cross-section, $(\mathbf{M})$ basal lamina cross-section, (N) detail of costa in upper lamina cross-section, $(\mathrm{O})$ detail of costa in basal lamina cross-section. Photos A-B and DG, I from sample coded 3230 (MUB 60458), C, H, J-O from sample coded 1321 (MUB 12650).

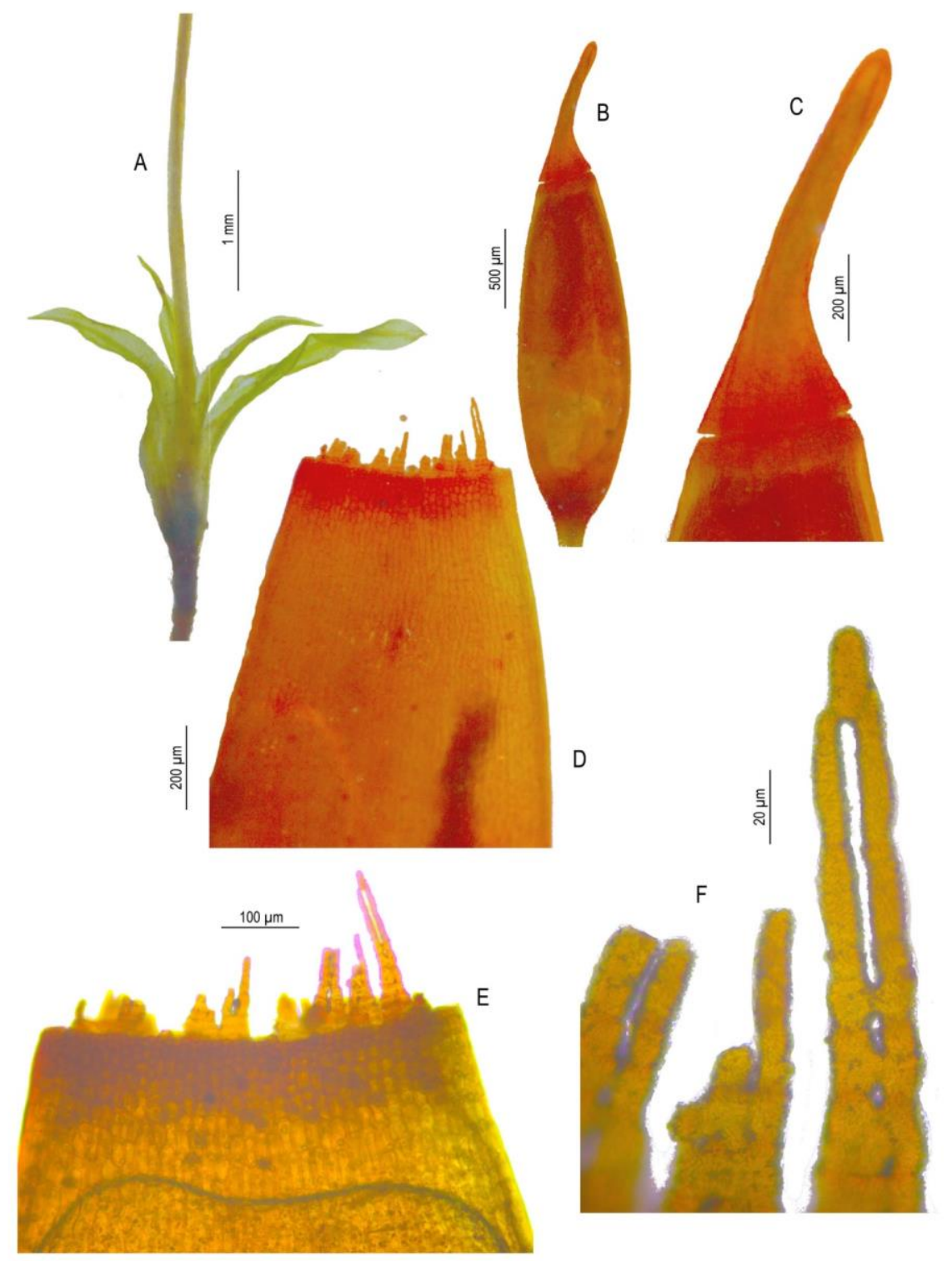

Figure 4. Macro- and microphotographs of perichaetium and sporophyte of Trichostomum brachydontium: (A) perichaetium, (B) capsule, (C) operculum, (D) upper part of capsule showing peristome, (E) mouth of capsule showing annulus and peristome, $(\mathbf{F})$ detail view of peristome teeth. All photos from sample coded 3230 (MUB 60458).

Other names for this basionym: Didymodon brachydontius (Bruch in F.A. Müll.) Wilson, Brit. Fl. (ed. 4) 2: 30. 1833 = Tortula brachydontia (Bruch in F.A. Müll.) Mitt., J. Linn. Soc., Bot. 12: 148. 1869 = Mollia brachydontia (Bruch in F.A. Müll.) Lindb., Musci Scand. 21. $1879 \equiv$ Tortella brachydontia (Bruch in F.A. Müll.) C.E.O. Jensen, Danmarks Mosser 2: 320. 1923.

Synonyms: 
Trichostomum mutabile Bruch ex De Not., illegitimate, superfluous, Syllab. Musc. 192. 1838 三 Trichostomum brachydontium subsp. mutabile (Bruch ex De Not.) Giacom. illegitimate, type of species included, Ist. Bot. Reale Univ. Reale Lab. Crittog. Pavia, Atti 4: 204. 1947.

Trichostomum mutabile var. cophocarpum Schimp., Syn. Musc. Eur. (ed. 2) 171. 1876. Type citation: "In Algarvia (H. Solms)". Lectotype (designated by Herzog [5]): [Portugal] Algarve, San Marcos da Serra inter cisteta c. frct!, leg. Solms, 66 (as T. cophocarpum Solms), GOET. Isotype: 237 cophocarpum Original JE04008872! = Mollia brachydontia var. cophocarpa (Schimp.) Braithw., Brit. Moss Fl. 1: 246. 1887 三 Trichostomum brachydontium var. cophocarpum (Schimp.) Cout., Musci Lusit. 36. 1917.

Hymenostomum unguiculatum H. Philib. in Schimp., Syn. Musc. Eur. (ed. 2) 37. 1876. Type citation: „in rupium calcarearum fissuris et in terra lapidosa prope Aix Gallo-Provinciae ubi clar. Prof. PIIILIBERT anno 1871 detexit et ipse, eo duce, anno 1872 legi; provenit sociis Weisia viridula, Trichostomo crispulo, Bryo torquescente etc. Fruct. matur. Aprili“. Isotype: Trichostomum gymnostomum sp. nov., Aix en Provence, vere 1872, HA.H3400240!; topotype: Hymenostomum unguiculatum Philb., in rupibus calcareis umbrosis prope Aix, 29 mai 1869, HA.H3400239! इ Trichostomum mutabile var. unguiculatum (H. Philib. in Schimp.) Husn., Muscol. Gall. 87. 1885 = Trichostomum brachydontium var. unguiculatum (H. Philib. in Schimp.) Corb. \& Jahand., Ann. Soc. Hist. Nat. Toulon 4 (Suppl.): 163. $1920 \equiv$ Trichostomum viridulum [unranked] unguiculatum (H. Philib. in Schimp.) Gams \& C. Cortés, invalid, rank not clearly indicated (mutsp.), Anales Inst. Bot. Cavanilles 13: 123. 1956.

Nomenclature - Bruch mentioned two syntypes in the protologue of Trichostomum brachydontium, one in continental Italy, "bei Spezzia", and the other in the Italian island of Sardinia, "bei Cagliari". Both syntypes were collected by F.A. Müller. More specifically, the Sardinian syntype was collected for "Unio Itineraria" (U.I.), also called "Botanischer Reiseverein" in Bruch's travels to the southeastern Alps, Istria and Sardinia [45], and to Algeria and Austro-Hungary between 1826 and 1828 [46]. Therefore, the Sardinian syntype of T. brachydontium is spread between many herbaria. In JE herbarium there is one exiccata of the Unio Itineraria of T. brachydontium from Sardinia collected by F.A. Müller, in which the number of the exiccata (229a) has been added later in pencil to the label. It was studied by the authors of this work and has been selected as the lectotype. The PC sample considered an isolectotype has the same printed label as the JE specimen but was not examined by the authors of this work. In both specimens only February is indicated as the date of collection, not the year. According to Wörz [45], F.A. Müller traveled to Sardinia for the U.I. in 1827, and therefore that should be the year of collection. Although in the protologue Bruch indicates "März und April", the date of the collection in the field is unknown, therefore the non-coincidence of the months mentioned in the protologue with that indicated in the lectotype label should not be considered a reason to reject our lectotypification. In JE herbarium there are another two specimens (JE 04008874 and JE 04005034) that could belong to the original material. In the first one, the same data as in the lectotype are handwritten and without mention to U.I., therefore it is here considered a syntype. In the JE 04005034 sample both original localities mentioned in the protologue are indicated on the label (Sardinia in fruticetis prope Cagliari $\mathcal{E}$ in aggere limoso prope Golfo di Spezzia), but as the true origin of the plants is unknown, we do not consider it a syntype.

In relation to the type of T. b. var. cophocarpum Herzog [5] (pp. 456 and 475) considered the GOET specimen to be the original material used by Schimper to describe the taxon, therefore, though not expressly mentioned, it should be considered the lectotype. Unfortunately, the specimen in GOET seems to be lost, or at least it was not found when the loan was requested. Fortunately, in the Herzog herbarium, preserved at JE, there is a small envelope without collection data, indicating only that it is the "cophocarpum original" material. It contains two complete fructified plants. They were probably detached from the original ex GOET that Herzog took as a duplicate and kept in his herbarium, and therefore the material should be considered an isotype. In the protologue Schimper [44] only mentions some characteristics in which this variety apparently differs from typical 
T. brachydontium: the acute to acuminate lanceolate leaves and the ovate, more solid and brown, capsule on a short seta and a mostly rudimentary peristome. In fact the plants have similar leaves to those of T. brachydontium s.s., being about $1 \mathrm{~cm}$ tall, greenish above and brown below, with narrowly lanceolate leaves, crispate when dry and erecto-patent when moist, $2.00-2.65 \times 0.33-0.55 \mathrm{~mm}$ (4.7 to 6.0 times as long as wide), with a short acuminate apex but not cuspidate, costa excurrent in a mucro up to $126 \mu \mathrm{m}$ long and basal margin of leaves entire, and a sporophyte with an orange seta 7.8-8.5 mm long, elipsoidal urn $1.10-1.20 \times 0.60-0.72 \mathrm{~mm}$, rudimentary peristome and spores very similar to those exemplified by T. brachydontium s.s., and therefore it should be considered a synonym of this species. Braithwaite [14] proposed the combination Mollia brachydontia var. cophocarpa (Schimp.) Braithw., but the description and comparison he made with the type species (Plants more slender, tall, bright green above, rufescent below; leaves lanceolate below, longer, acutely acuminate; caps. on a shorter pedicel, oval, brown, peristome very rudimentary) do not correspond to the characteristics of the original material of T. brachydontium var. cophocarpum, as was highlighted by Herzog [5] (pp. 475), but to T. brachydontium var. cuspidatum.

Concerning the type of Hymenostomum unguiculatum H. Philib. in Schimp., the study of an isotype and a topotype kept at $\mathrm{H}$ herbarium revealed that these specimens correspond to T. brachydontium s.s. A third specimen at H (HA.H3400241) coming from the same locality and collected in 1874 was identified by the authors of this work as T. brachydontium var. cuspidatum, therefore it must be rejected as original material. Other original specimens of Philibert kept at AUT herbarium could not be studied but were analysed by means of a high resolution photograph of the herbarium plate kindly sent by the AUT curator to the authors of this work. In this photograph, the size of plants, greater than 1 $\mathrm{cm}$ in length, led us to conclude that these collections also correspond to T. brachydontium s.s. Consequently, we propose that T. brachydontium var. unguiculatum is a synonym of $T$. brachydontium s.s.

Morphological Description - Plants medium, (0.7-)1.0-2.0 cm tall, bright green above, brown below, in tufts; stems tomentose, several times branched by the growth of innovations, distinctly interrupted, each innovation with smaller scale-like lower leaves becoming progressively larger up stem and sometimes distinctly comose; flagelliform shoots not seen; stem cross-section rounded, 150-300 $\mu \mathrm{m}$ wide, hyalodermis irregularly present, central strand present, sometimes poorly developed; axillary hairs hyaline, up to 10 cells long, basal cell shorter; basal leaves short-triangular to ovate, apex obtuse, sharply narrowed to acute, margins entire or slightly toothed from base to apex, costa excurrent in a short mucro; median and upper leaves crispate when dry, patent to spreading when moist, the apical with the tips recurved, narrowly lingulate to narrowly lanceolate to ensiform, sometimes narrowed at base, (1.35-)1.80-3.00(-3.80) x 0.30-0.50(-0.60) $\mathrm{mm}$ (5.0 to 8.0 times as long as wide), lamina flat to slightly canaliculate, frequently twisted, with a more or less erect basal part, slightly sheathing the stem, but not or scarcely expanded, yellowish or hyaline, contrasting with upper part, usually markedly undulate above the basal part, sometimes slightly undulate, straight to curved, unistratose, fragile, breaking easily when dissecting; apex short-acuminate or more rarely acute; margins plane or incurved below, plane in the upper part, entire or slightly toothed in the third basal part, papillose-crenulate above; costa greenish, gradually narrowing from base to apex, 63-120 $\mu \mathrm{m}$ wide at base, excurrent in an arista, (50-)90-150 $\mu \mathrm{m}$ long, plane-convex in cross-section with two well developed stereid bands, up to 9 guide cells in the basal part of leaf and 3-4 in the upper part, one row of ventral cells and one row of dorsal cells, dorsal side of costa smooth or slightly papillose; laminal cells mid-basal and paracostals long rectangular and thin-walled, marginal basal cells longer and narrower, with 1-2 rows ascending the lamina and exceeding the transitional papillose cell area, upper cells quadrate to shortly rectangular, sometimes oblate, 5.0-6.5 x 5.0-8.0 $\mu \mathrm{m}$, opaque, with several bifurcate, blunt papillae, frequently more developed in the ventral side, marginal cells in the median and upper part not differentiated, sometimes less papillose; dioicous?; perigonia not seen; perichaetia apical; perichaetial leaves usually similar to vegetative leaves, but internal ones narrower with longer 
acuminate apex. Seta (5)10-20 mm long, yellowish; capsules ellipsoidal to cylindrical, orange, $1.20-2.20$ x 0.40-0.65 mm; operculum longly rostrate, erect or inclined, $0.70-1.00 \mathrm{~mm}$ long; annulus persistent, formed by 3-4 rows of quadrate, thick-walled, reddish cells; peristome rudimentary to well developed, when rudimentary formed by a short smooth basal membrane, apparently absent, or by small papillose segments arising from a basal membrane, not exceeding the mouth of the urn, when well developed formed by bifurcate, perforate, orange, papillose teeth, up to $250 \mu \mathrm{m}$ long; spores 13-20 $\mu \mathrm{m}$, densely and regularly warty.

Distribution and habitat - Herzog [5] remarked on the wide and fragmented distribution of this species, centred on Macaronesia and the western Mediterranean, with occurrences from the British Isles east to the Caucasus. He listed Macaronesia (Azores, Canary Islands, Madeira), Balearic Islands, Channel Islands, Corsica, France, Great Britain (England, Scotland), Italy, Portugal, Sardinia, Spain, as well as Japan, New Zealand and Réunion. From our study we can confirm Macaronesia (Canary Islands), Balearic Islands, Greece, Italy, Portugal, Sardinia, Spain, and also Morocco. Its true distribution elsewhere, including North, Central and South America, Africa, Indian Ocean Islands, and Australia [2] is uncertain because of taxonomic issues and indeed the present study has suggested further undescribed taxa (unpub.) exist. Based on occurrences in European countries, $T$. brachydontium s.l. appears to be preferential for warmer regions [47], though surprisingly it is not reported for Gibraltar, Malta, or Netherlands. Further east it is apparently rare or absent, and has not been reported for Poland and many countries in European Russia (but present in Ukraine). It is Red Listed for Bulgaria, Estonia, Germany, Luxembourg and Slovenia [47]. From the present study T. brachydontium appears to be tolerant of a wide range of conditions, recorded from insolated situations where it is subject to periodic desiccation such as semi-fixed dunes and exposed rocks, to humid habitats including barrancos (ravines), autochthonous woodland and on stream banks. It is apparently indifferent to substrate, from base-rich to acid, occurring on soils, protosoils, soil-filled rock crevices, on organic material (humus) and even epiphytic (on Rhododendron in humid ravines), predominately at low to moderate elevations; material studied ranged from near sea-level to $670 \mathrm{~m}$ (Greece).

(1.1) Trichostomum brachydontium var. cylindricum (Schimp.) Cout., Musci Lusit. 36. 1917.

Basionym: Trichostomum mutabile var. cylindricum Schimp., Syn. Musc. Eur. (ed. 2) 171. 1876. Type citation: “In Algarvia (H. Solms)". Lectotype (designated by Herzog [5]): [Portugal] Flora Lusitanica Algarve, 110 Trichostomum mutabile Schimper .... Monchique, Serra da Picota, Barranco do Banho, colleg. 1866, H. CR.Z. Solms, GOET!.

Nomenclature - Herzog [5] (pp. 456 and 474) considered the GOET specimen to be the original material used by Schimper to describe the taxon, and therefore we accept it as the lectotype.

Diagnostic characters - Schimper described this taxon in the protologue as having leaves slightly different from type form in leaf shape, apex, costa and mucro and capsule oblong-cylindrical on a long seta and peristome teeth fairly regular, scarcely articulated and slightly papillose. Study of the type specimen allowed the authors of this work to ascertain that the only reliable characters of var. cylindricum that separates it from other specimens examined is the long cylindrical urn of the capsule measuring $2.0 \times 0.4 \mathrm{~mm}$. The other characteristics have been observed in other specimens of T. brachydontium s.s., including a long seta up to $1.5 \mathrm{~cm}$ and the well-developed peristome teeth, formed by bifurcate, yellowish teeth, up to $160 \mu \mathrm{m}$ long. For the moment we can only hypothesize that the variation in capsule size and shape may be due to environmentally induced variation, and that it should be studied further by the sequencing of other specimens with this morphology. Therefore, pending further work, we retain the taxon at varietal level.

(2) Trichostomum herzogii Ros, O.Werner \& R.D.Porley nom. nov. (Figure 5). 
Trichostomum cuspidatum Schimp., nom. illeg., Syn. Musc. Eur. (ed. 2) 181. 1876. Type citation: "Ad rupes calcareas Hohenstein pr. Warstein Westphaliae socia Solorina saccata (Dr. H. Müller)". Lectotype (designated by Herzog [5]): [Germany] Trichostomum cuspidatum $=$ T. mutabile var. cuspidatum Schimper, Limpr. (Synopsis ed. II), Flora von Westfalen, auf Kalkfelsen des Hohensteins bei Warburg, leg. et mihit 111, steril (Collector unknown s.n., s.d.) (Herb. T. Herzog ex Herb. A. Geheeb) JE 04008876!. Isotypes: Westfalens Laubmoose, 205. Trichostomum mutabile Brch., unfructbar, Veräntlicher Haartmund. Am Massenkalkfels des Hohenstein bei Warstein, nur unfructbar und mit männlichen Blüthen. Dr. H. Müller, JE 04008877!; Trichostomum mutabile, Warstein, HM. 267 (Herb. Hermann Winter, Gotha), JE 04008878!.

Other names for this basionym: Mollia cuspidata Braithw., Brit. Moss Fl. 1: 230. 1887 三 Trichostomum mutabile var. cuspidatum (Braithw.) Limpr., Laubm. Deutschl. 1: $50.1888 \equiv$ Trichostomum brachydontium subsp. cuspidatum (Braithw.) Giacom., Ist. Bot. Reale Univ. Reale Lab. Crittog. Pavia, Atti 4: 204. 1947 = Trichostomum mutabile subsp. cuspidatum (Braithw.) Podp., Consp. Musc. Eur. 196. $1954 \equiv$ Trichostomum brachydontium var. cuspidatum (Braithw.) L.I. Savicz, Bot. Mater. Otd. Sporov. Rast. Bot. Inst. Komarova Akad. Nauk S.S.S.R. 11: 208. 1956.

Nomenclature - Herzog [5] (pp. 477) mentioned the label data of JE 04008876 exemplar as being Schimper's original material of T. cuspidatum, and therefore it should be considered as the lectotype. Herzog also studied another specimen in Geheeb Herbarium (Trichostomum mutabile Bruch, Nur steril in Klüften der Massenkalkfelsen im Lürmekethal [Lörmecketal] u. am Hohen Stein bei Warstein im Sauerland u. bei Höxter, Dr. H. Müller au Wenck (Herb. E. Wenck), JE 04008875!), but as three localities are given on the label (prompting Herzog to annotate in pencil on the label "Woher stammt nun dieses Expl?"), the specimen should not be considered an isotype, in spite of its morphology corresponding to T. herzogii.

Etymology - Because T. cuspidatum Schimp. is an illegitimate name and later homonym, we propose here a new name for this species in honor of the German bryologist Theodor Karl Julius Herzog (1880-1961), for his pioneering study of the T. brachydontium complex at the beginning of the $20^{\text {th }}$ century. He correctly interpreted the morphological traits of this difficult and variable complex. Regrettably, his results were not taken seriously or simply ignored by his contemporaries and later workers, resulting in only one accepted species in modern bryological floras. However, some 100 years later, his approach has been vindicated by employing molecular methods. 

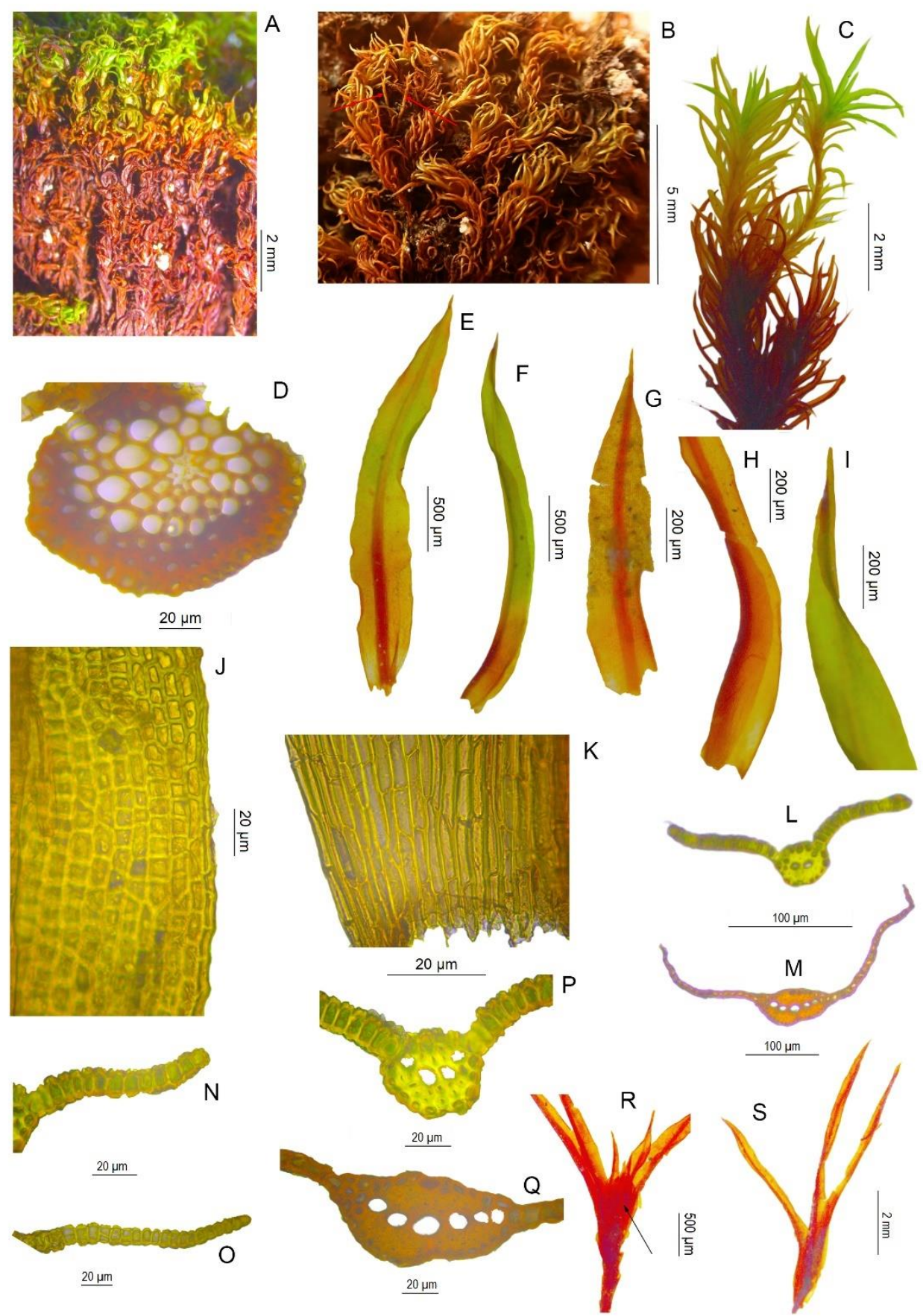

$20 \mu \mathrm{m}$

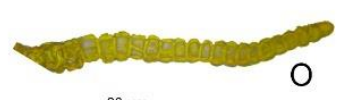

$\underline{20 \mu \mathrm{m}}$

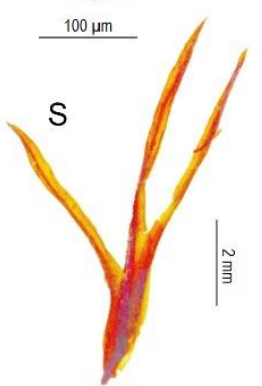

Figure 5. Macro- and microphotographs of gametophyte of Trichostomum herzogii: (A) plants showing yellowish green color above, reddish below, (B) tuft showing flagelliform shoots (red arrows), (C) Individual plant showing non-comose stems, (D) stem crosssection, (E, F, G) apical and median leaves, (H) concolorous and canaliculate basal part of leaf, not contrasting with upper part, (I) upper part of leaf showing long-acuminate apex, $(\mathbf{J})$ margin near base of lamina with weakly developed teeth, (K) basal hemilimb of leaf showing narrow-rectangular, thick-walled paracostal cells, (L) leaf cross-section in upper lamina, (M) leaf cross-section in basal lamina, (N) upper lamina cross-section, $(\mathbf{O})$ basal lamina cross-section, $(\mathbf{P})$ detail of costa in upper lamina cross-section, $(\mathbf{Q})$ detail of costa in basal lamina cross-section, (R) axillary perigonium (black arrow), (S) perichaetium. Photos A, D, H, K-Q and S from sample coded 3291 (MUB 60473), B from sample R.D. Porley 1470, Herb. Porley, C, E, F, I, and J from sample coded 3300 (MUB 60457), G from isotype JE 04008878, R from isotype JE 04008877.

Morphological description - Plants medium to large, (1.0)2.0-3.0(-5.0) cm tall, yellowish green above, reddish below, in tufts; stems tomentose, several times branched, innovations not clearly differentiated, distinctly interrupted or not, each branch with lower leaves shorter than those above, becoming progressively larger up stem but not distinctly 
comose; flagelliform shoots sometimes present; stem cross-section rounded, 150-180 $\mu$ m wide, hyalodermis irregularly present, central strand present, sometimes poorly developed; axillary hairs hyaline, up to 10 cells long, basal cell shorter; basal leaves scarcely differentiated; median and upper leaves incurved or crispate when dry (depending on the length, the longer the leaves the more crispate), erect to erect-patent when moist, the apical sometimes spreading, linear-lanceolate, (1.22-)2.00-3.45(-3.61) x (0.21-)0.35-0.50(-0.57) mm (5.0 to 7.6(8.9) times as long as wide), lamina strongly canaliculate, not twisted, with a more or less erect basal part, sheathing the stem and expanded, concolorous with upper part, not or undulate above the basal part, straight to sigmoid, unistratose, rarely bistratose patches in the lower lamina, not fragile; apex long-acuminate to subulate; margins incurved from below to the upper part, entire or obscurely toothed in the third basal part, papillosecrenulate above; costa reddish, gradually narrowing from base to apex, 50-150 $\mu \mathrm{m}$ wide at base, excurrent in an arista, 70-150 $\mu \mathrm{m}$ long, biconvex in basal lamina cross-section, planoconvex in the rest of lamina, with two well developed stereid bands, up to 8 guide cells in the leaf base and 2 in the upper part, one row of ventral cells and one row of dorsal cells, dorsal side of costa smooth or slightly papillose; laminal cells mid-basal and paracostals rectangular, sometimes very narrow-rectangular, usually thick-walled, obscurely nodulose, marginal basal cells longer, narrower and thin-walled, with 2-3 rows ascending the lamina and exceeding the transitional papillose cell area, upper cells quadrate to shortly rectangular, sometimes oblate, 5.0-6.5(-8) x 5.0-6.5(-8.0) $\mu \mathrm{m}$, opaque, with several bifurcate, blunt papillae, frequently more developed on the ventral side, marginal cells in the median and upper part not differentiated, sometimes less papillose and oblate; dioicous; perigonia in branch axils; perigonial leaves similar to vegetative leaves but smaller; perichaetia in branch axils; perichaetial leaves similar to vegetative leaves, sometimes with longer acuminate apex; sporophytes not seen.

Observations - The specimens sequenced in the present work are generally larger than the types studied. In particular, the British plants from Water-Cum-Jolly Dale (DNA code 3291) attain $5 \mathrm{~cm}$ in length and the French plants (DNA code 3300) $3 \mathrm{~cm}$, the latter specimen also having longer leaves with a higher L/W ratio, up to 8.9, whereas the German type specimens studied are $2-3 \mathrm{~cm}$ in length and the leaves are shorter, with a maximal length/width ratio of 7.6. The three German type specimens and a British specimen (Alberbury, R.D. Porley 1391) include male plants, while the British specimen (DNA code 3291) includes female plants. Fully developed sporophytes have not been observed in material studied for this work, though in a French specimen from Aix en Provence (HA.H3400241) the vestige of a seta is present. Other authors (eg: [14]) described the sporophyte as having an oval brown capsule on a shorter pedicel, and a very rudimentary peristome, but if it corresponds to this species of T. brachydontium s.s. is doubtful as this author confused var. cuspidatum with var. cophocarpum.

Distribution and habitat - In contrast to the other species, Herzog [5] noted that this taxon is absent from the Mediterranean basin, occurring in the southern foothills of the Alps and in the mountains of Central Europe, extending east to the British Isles and to southern Sweden. He reports it is widespread within this area and gives Austria, France, Germany, Great Britain (England, Wales), Italy, Sweden and Switzerland. The present study has confirmed it for France, Germany, Great Britain (England, Wales) and Italy. As this species has been confused with T. brachydontium var. cophocarpum so the distribution of T. herzogii is incompletely known, at least in Britain. Trichostomum brachydontium var. cuspidatum is reported for Madeira [10] with the caveat that all material needs revising, but its occurrence here is most unlikely. Our data regarding habitat agrees with Herzog [5] that it is characteristic of limestone cliffs, but it also occurs on damp base-rich montane rock ledges, in gorges and on calcareous rock outcrops in upland grassland, in open or partially shaded situations. Data from the few specimens we have seen indicate T. herzogii occurs at moderate to high elevations, from c. $100 \mathrm{~m}$ to $950 \mathrm{~m}$ in Britain, but throughout its Central European range it is likely to occur at higher altitudes.

(3) Trichostomum littorale Mitt., J. Bot. 6: 99. pl. 77: f. 7-9. 1868 (Figure 6). 
Type citation: "Ireland (Drummond); Whitsand Bay, Cornwall (Mr. Brent, communicated by Mr. Holmes), below the cliffs, east of Hastings, in sandy ground". Lectotype (designated here): (dubl) Trichostomum mutabile Botsch (Wilson), Ireland, Div. 28, Gymnostomum tortile Schwaegr, NY 01449062!. Syntypes: [Great Britain] Trichostomum l., Whitstand Bay Cornwall, Mr. F. Brent, 3.2.68, NY 01449063!; [Great Britain] Trichostomum litorale Mitt., in large yellow patches a little East of Fairlight Down near Hastings, Sussex, W.M., July 1847, NY 01449064!.

Other names for this basionym: Mollia littoralis (Mitt.) Braithw., Brit. Moss Fl. 1: 244. 35 E. $1887 \equiv$ Trichostomum mutabile var. littorale (Mitt.) Dixon \& Jameson, Stud. Handb. Brit. Mosses 216. 1896 三 Didymodon littoralis (Mitt.) Kindb., Eur. N. Amer. Bryin. 2: 275. $1897 \equiv$ Tortella brachydontia var. littoralis (Mitt.) C.E.O. Jensen, Danmarks Mosser 2: 321. $1923 \equiv$ Trichostomum brachydontium var. littorale (Mitt.) C.E.O. Jensen, Förteckn. Skand. Växt., Moss. (ed. 2). Mossor (Andra Upplagan) 25. 1937 三 Trichostomum mutabile subsp. littorale (Mitt.) Podp., Consp. Musc. Eur. 195. 1954.

Nomenclature - Mitten [48] mentioned three syntypes in the protologue of T. littorale, one from Ireland and two from the United Kingdom. The three syntypes are kept in the Mitten herbarium at NY. The syntype from Ireland (NY 01449062) is the more substantial collection and contains the largest plants, up to $3 \mathrm{~cm}$ high. The British syntype from Cornwall (NY 01449063) is sparse and contains smaller plants, about $1 \mathrm{~cm}$ high. The other British syntype, from East Sussex (NY 01449064), is also ample and of a similar size to the former. Mitten [48] (plate 77) illustrated both plant sizes in the original publication of the species. The syntype from Ireland, although containing no information regarding collector or date, has been selected as the lectotype due to the better development of the plants. Mitten did not mention in the protologue the denticulate margins a short distance above the leaf base, possibly because the British syntypes are rather poorly developed. Nevertheless, it was later correctly highlighted in later works such as Husnot [43], Dixon \& Jameson [15] and Herzog [5].

Morphological description - Plants medium to large, (0.5-)1.5-3.0 cm tall, bright green above, brown below, in cushions or tufts; stems not tomentose, several times branched by the growth of innovations, distinctly interrupted and comose, each innovation with smaller scale-like lower leaves becoming progressively larger up stem, apical leaves crowded, forming a comal tuft; flagelliform shoots sometimes present, up to fascicles of 5, 2-3 mm long; stem cross-section rounded, 160-180 $\mu \mathrm{m}$ wide, hyalodermis irregularly present, central strand present, sometimes poorly developed; axillary hairs hyaline, up to 10 cells long, basal cell shorter; basal leaves short-triangular to ovate, apex obtuse, margins dentate from base to apex, costa usually not excurrent; median and upper leaves incurved or slightly crispate when dry, erect to erect-patent when moist, comal leaves spreading or with the tips recurved, lingulate or oblong-lingulate, sometimes slightly lanceolate or spatulate, slightly narrowed at base, sometimes constricted at transitional zone, (0.60)1.00-1.90(-2.30) x 0.20-0.40(-0.50) $\mathrm{mm}$ (3.0 to 4.6(-6.6) times as long as wide), lamina canaliculate, not twisted, with a more or less erect basal part, slightly sheathing the stem, but not or scarcely expanded, yellowish or hyaline in an oval zone of basal part, sharply differentiated from other basal cells and contrasting with the upper part, slightly undulate above the basal part, curved to sigmoid, unistratose, rarely bistratose patches in the lower lamina, not fragile, does not break easily when dissecting; apex obtuse, mucronate, sometimes weakly cucullate; margins plane or incurved below, incurved in the upper part, usually strongly irregularly toothed in the third basal part, teeth sometimes recurved, rarely bifurcate, sometimes scarcely developed, papillose-crenulate above; costa mostly greenish, rarely red, gradually narrowing from base to apex, (40-)50-90(-125) $\mu \mathrm{m}$ wide at the base, excurrent in a mucro, 20-85 $\mu \mathrm{m}$ long, occasionally unguiculate, plane-convex in cross-section with two well developed stereid bands, up to 8 guide cells in the basal part of leaf and 3-4 in the upper part, one row of ventral cells and one row of dorsal cells, dorsal side of costa slightly to coarsely papillose, smooth at apex; laminal cells paracostal basal cells long rectangular, sometimes thick-walled, mid-basal cells shorter and marginal basal cells longer, narrower and thin-walled, with 1-2 rows ascending the lamina and exceeding the 
transitional papillose cell area, upper cells quadrate to shortly-rectangular, 5.0-8.0(-9.5) $\mathrm{x}$ 5.0-8.0 $\mu \mathrm{m}$, opaque, with several bifurcate, blunt or rarely sharp papillae, more developed on the ventral side, marginal cells in the median and upper part not differentiated, sometimes less papillose; dioicous; perigonia not seen; perichaetia in leaf axils and at stem apex; perichaetial leaves acute, inner most lanceolate with acuminate apex; sporophytes not seen.

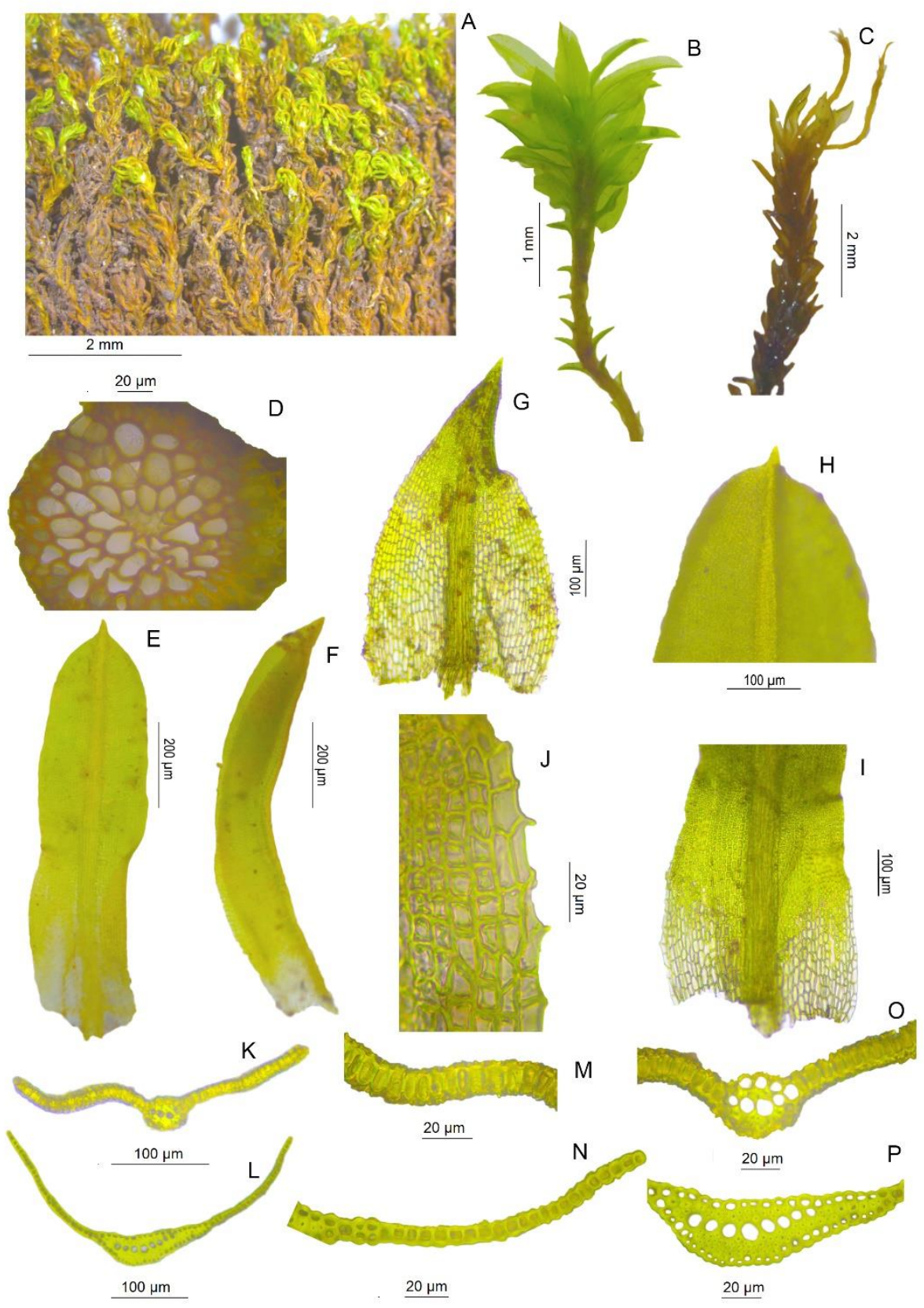

Figure 6. Macro- and microphotographs of gametophyte of Trichostomum littorale: (A) plants showing bright green color above, brown below, (B) comose innovation, (C) flagelliform shoots arising from apical branch, (D) stem cross-section, (E, F) apical and median leaves, (G) scale-like basal leaf with dentate margins from base to apex, (H) upper part of leaf showing obtuse mucronate apex, (I) hyaline basal part of leaf scarcely expanded, contrasting with upper part, (J) margin near base of lamina with strongly irregular teeth, (K) leaf cross-section in upper lamina, (L) leaf cross-section in basal lamina, (M) upper lamina cross-section, (N) basal lamina crosssection, (O) detail of costa in upper lamina cross-section, (P) detail of costa in basal lamina cross-section. Photos A, E, F from sample coded 3233 (MUB 60478), B, G, I from sample coded 3299 (MUB 60485), C from sample coded 3202 (MUB 60475), D, K-P from sample coded 3240 (MUB 60481), H from sample coded 3235 (MUB 60479), J from lectotype NY01449062.

Distribution and habitat - This species is characteristic of oceanic climates, with an Atlantic distribution, on the western seaboard of Europe [49], an observation supported 
by our own studies. Herzog [5] lists Belgium, Channel Islands, France, Great Britain (England, Scotland, Wales), Ireland, Italy, and Sardinia. Mönkemeyer [41] reported to be present also in southern and central Europe, Norwegen and on Bornholm Island (Denmark). It is also reported for Madeira [10] and Faroes [50]. During the present study we have seen specimens from Great Britain (England, Scotland, Wales), Ireland, Portugal and Spain (Cádiz). Data from the present study reveals that it has a preference for sheltered niches, mostly on rock (schists, granite, syenite) in block-fields, or on soil-filled fissures on rocks and occasionally on soil, usually in shade but sometimes insolated. Typical habitats include rocky barrancos, north-facing rocky mountain slopes, terrace walls, by cascades, spring-heads and rocky cliffs above streams, in woodlands (Quercus spp., Castanea sativa) and, in Ireland, on lake-side boulders. It is also reported from coastal rocks in Faroes, Great Britain and Norway [50]. The material studied exhibited an elevational range from near sea-level to $815 \mathrm{~m}$ (Serra de Monchique, Portugal).

(4) Trichostomum meridionale Ros, O.Werner, R.D.Porley sp. nov. (Figures 7, 8).

Holotype:-SPAIN. Murcia Region, Murcia, El Valle Perdido, proximidades a San-

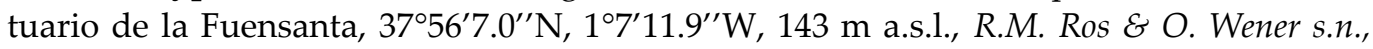
14.03.2020, DNA code 3268 (MUB 60295). Isotypes: (MA, Herb. Porley).

Diagnosis - Trichostomum meridionale can be distinguished by plants $0.3-0.5(-1.0) \mathrm{cm}$ tall, in dense and short turfs; stems comose; leaves incurved when dry and erect to erectpatent, or comal leaves spreading when moist, lingulate to spatulate, occasionally panduriform or lanceolate, $0.90-1.90(-2.30) \times(0.20-) 0.30-0.50(-0.60) \mathrm{mm}$ (3.4 to 4.0 times as long as wide); lamina flat to canaliculate, slightly undulate above the basal part, straight to curved, unistratose, not fragile; apex obtuse and mucronate; margins plane or incurved below, more incurved in the upper part, entire or slightly denticulate in the third basal part; costa gradually narrowing from mid-leaf to apex, excurrent in a mucro 25-60 $\mu \mathrm{m}$ long; mid-basal and paracostal cells long rectangular and thin-walled, marginal basal cells longer and narrower; upper cells quadrate to shortly rectangular, 5.0-8.0 x 5.0-8.0 $\mu \mathrm{m}$, opaque, with several bifurcate blunt papillae, more developed in the ventral side; dioicous; sporophyte usually present, with seta 5-10 mm long, urn ellipsoidal to cylindrical, yellow-red, 1.00-1.50 x 0.35-0.60 mm; peristome absent or rudimentary, formed by a short membrane or by small papillose segments arising from basal membrane, not exceeding the mouth of the urn, with bifurcate, perforate, hyaline to pale orange, papillose teeth, up to $55 \mu \mathrm{m}$ long; spores $14-20 \mu \mathrm{m}$, densely and irregularly warty.

Paratypes:- GREECE, Eastern Aegean Islands, Rhodes, ca $1.2 \mathrm{~km}$ SE of Moni Artamiti, ca, 240 m, T.L. Blockeel 47/027, 08.03.2018, DNA code 3227 (Herb. Blockeel, duplicate MUB 60472).

SPAIN. Murcia Region: Cartagena, Sierra Minera de Cartagena-La Unión, Rambla

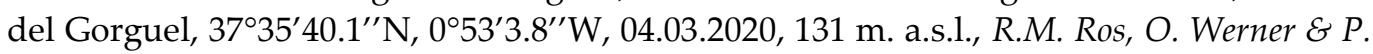
Egea Benavente s.n., DNA code 3259 (MUB 60287, Herb. Porley). Cartagena, Atamaría, camino que sube al monte de las Cenizas, en la carretera RM-514, 37 $35^{\prime} 37.58^{\prime \prime} \mathrm{N}$, 049'21.94”'W, 04.03.2020, 151 m. a.s.l., R.M. Ros, O. Werner E P. Egea Benavente s.n., DNA code 3261 (MUB 60289, Herb. Porley). Ibidem, DNA code 3260 (MUB 60288, Herb. Porley).

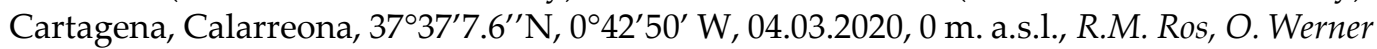
$\mathcal{E}$ P. Egea Benavente s.n., DNA code 3262 (MUB 60290, Herb. Porley); Ibidem, DNA code 3263 (MUB 60291, Herb. Porley); Murcia, Rambla del Puerto de La Cadena, 3754'31.46”N, 19'43.75”'W, 260 m a.s.l., R.M. Ros E M. Farag s.n., 26.03.2019, DNA code 3266 (MUB 60292, Herb. Porley); Murcia, El Valle Perdido, proximidades a Santuario de la Fuensanta,

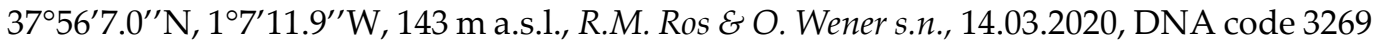
(MUB 60294, Herb. Porley); Las Torres de Cotillas, urbanización Los Romeros, calle I, parcela en la zona más alta, $38^{\circ} 00^{\prime} 35.76^{\prime \prime} \mathrm{N}, 1^{\circ} 14^{\prime} 36.77^{\prime \prime} \mathrm{W}, 144 \mathrm{~m}$ a.s.1., R.M. Ros s.n., 07.03.2020, DNA code 3264 (MUB 60293, Herb. Porley); Ibidem, 02.05.2020, DNA code 3265 (MUB 60296, Herb. Porley). 


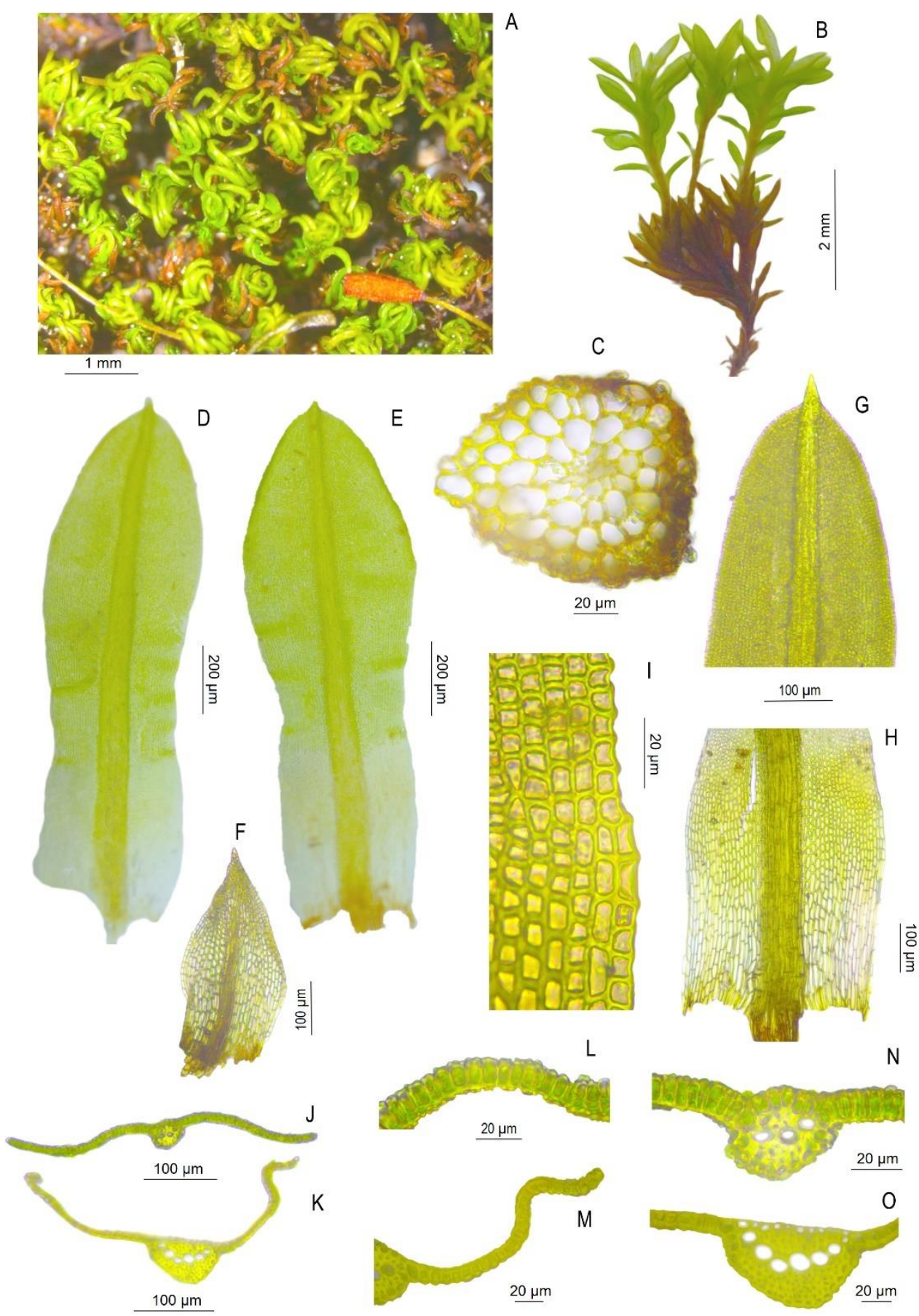

Figure 6. Macro- and microphotographs of gametophyte of Trichostomum meridionale: (A) habit of fertile plants, (B) comose stem ramification, (C) stem cross-section, (D, E) apical and median leaves, , (F) scale-like basal leaf, (G) upper part of leaf showing obtuse mucronate apex, $(\mathbf{H})$ hyaline basal part of leaf not expanded, (I) margin near base of leaf lamina with weakly developed teeth, (J) leaf cross-section in upper lamina, (K) leaf cross-section in basal lamina, (L) upper lamina cross-section, (M) basal lamina cross-section, (N) detail of costa in upper lamina cross-section, (O) detail of costa in basal lamina cross-section. Photos A from sample coded 3264 (MUB 60293), B, C-E, K, M, N from sample coded 3259 (MUB 60287), F-L, O from holotype, sample coded 3268 (MUB 60295 ). 

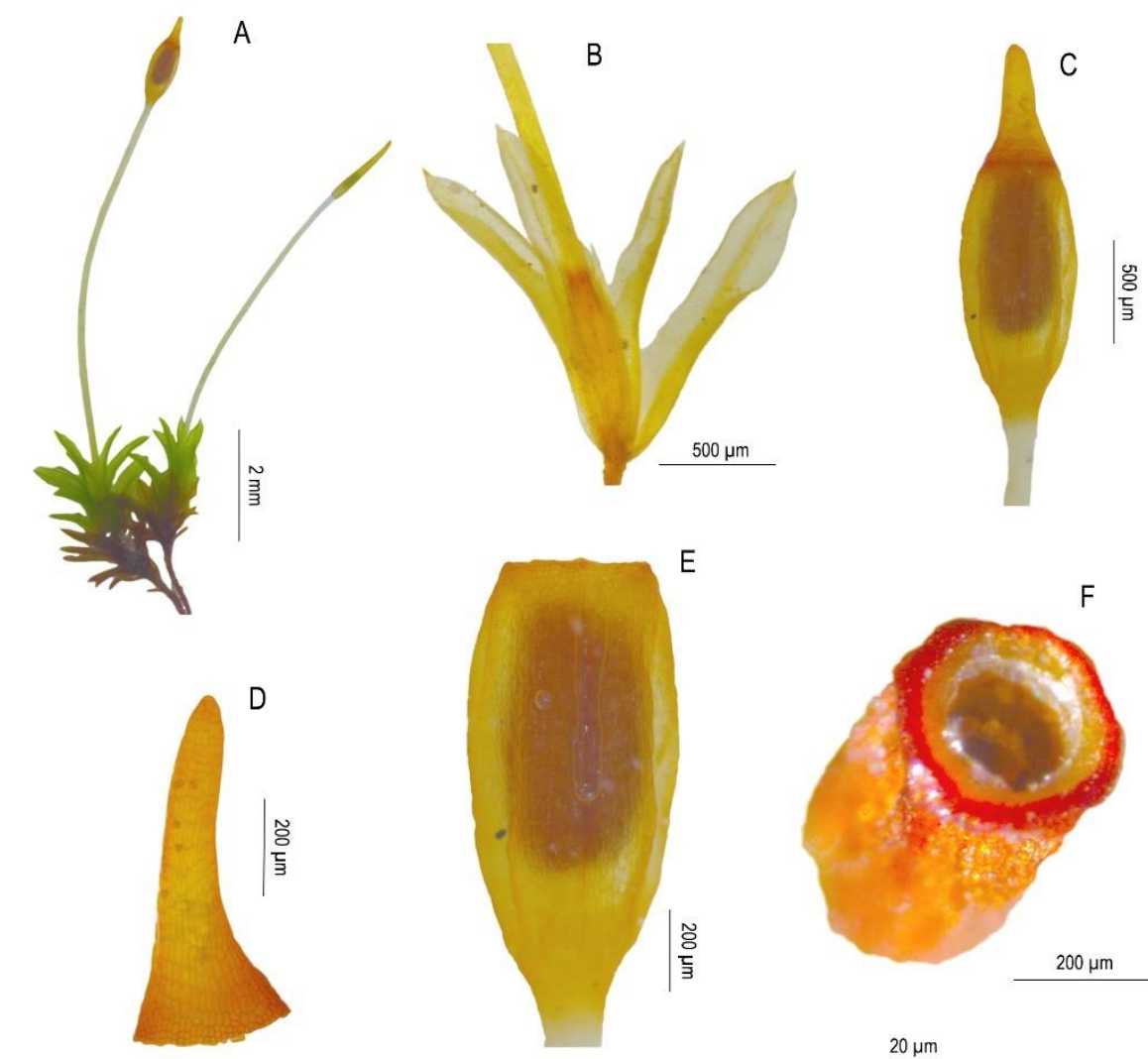

E
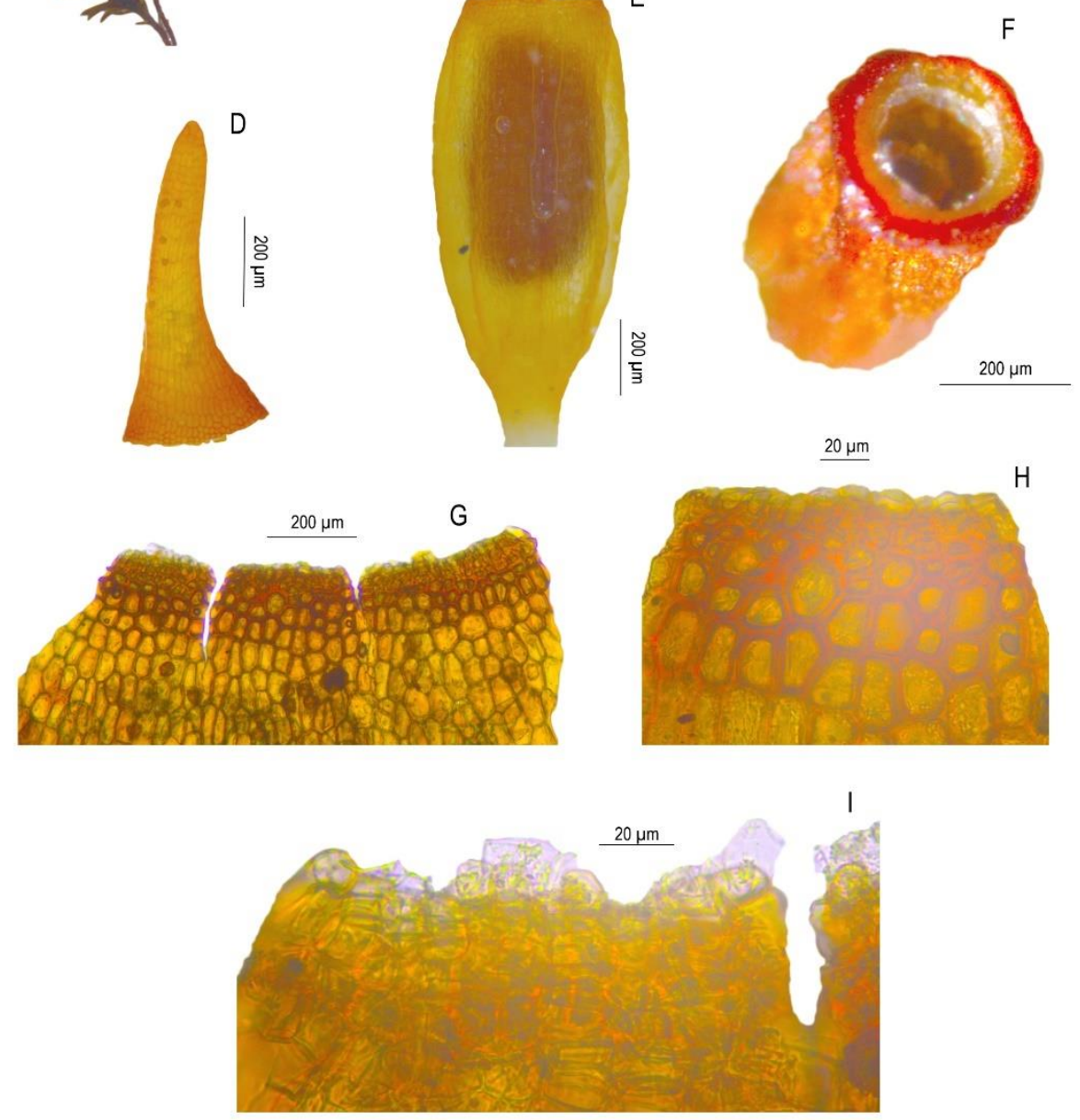

Figure 7. Macro- and microphotographs of perichaetium and sporophyte of Trichostomum meridionale: (A) fructified plants, (B) perichaetium, (C) capsule, (D) operculum, (E) deoperculated capsule, (F) overhead view of a capsule showing a rudimentary hyaline peristome not exceeding the mouth of the urn, $(\mathbf{G})$ detail view of the mouth capsule, $(\mathbf{H})$ external detail view of capsule mouth showing annulus cells, $(\mathbf{G})$ internal detail view of capsule mouth showing a rudimentary peristome formed by short, hyaline, papillose small segments arising from basal membrane. Photos A, C, E, G-I from sample coded 3259 (MUB 60287), B from sample MUB 5565, D from sample coded 3264 (MUB 60293), F from sample coded 3261 (MUB 60289).

Synonyms - Trichostomum mutabile var. densum Bruch \& Schimp., Bryol. Eur. 2: 122. pl. 174: B (fasc. 18-20. Mon. 16. pl. 5: B). $1843 \equiv$ Trichostomum mutabile subsp. densum (Bruch \& Schimp.) J.J. Amann, Fl. Mouss. Suisse 2: 96. 1918 = Trichostomum brachydontium subsp. densum (Bruch \& Schimp.) Giacom., Ist. Bot. Reale Univ. Reale Lab. Crittog. Pavia, Atti 4: 
204. 1947 三 Trichostomum brachydontium var. densum (Bruch \& Schimp.) Düll, Bryol. Beitr. 4: 90. 1984. Type not seen.

Nomenclature - Cortes Latorre [51] and Esteve Chueca \& Cortes Latorre [52] reported Trichostomum brachydontium var. unguiculatum (H. Philib. in Schimp.) Corb. \& Jahand. from the Murcian littoral mountains in the neighborhood of Cartagena (SE Spain), a taxon described in Schimper [44] from Aix en Provence (France) as Hymenostomum unguiculatum H. Philib. in Schimp. The latter, as explained in the nomenclature section of T. brachydontium s.s., is here considered a synonym of the former species.

Morphological description - Plants small, 0.3-0.5(-1.0) cm tall, bright green above, yellow to brown below, in dense and short turfs; stems not tomentose, not or scarcely branched by the growth of innovations, distinctly interrupted or not (depending on the size of plants, when very short than not distinctly interrupted) and comose, each innovation with smaller lower leaves becoming progressively larger up stem, the apical leaves crowded forming a comal tuft; flagelliform shoots not seen; stem cross-section rounded, up to $140 \mu \mathrm{m}$ wide, hyalodermis irregularly present, central strand well developed; axillary hairs hyaline, up to 10 cells long, basal cells shorter; basal leaves short-triangular, apex acute, margins entire or slightly toothed from base to apex, costa ending below apex or excurrent in a short mucro; median and upper leaves incurved when dry, erect-patent to patent, comal leaves more rarely spreading when moist, lingulate to spatulate, occasionally panduriform or lanceolate, $0.90-1.90(-2.30) \times(0.20-) 0.30-0.50(-0.60) \mathrm{mm}(3.4$ to 4.0 times as long as wide), lamina flat to canaliculate, not twisted, with basal part not or slightly sheathing the stem, not or scarcely expanded, yellowish or hyaline, contrasting with upper part, slightly undulate above the basal part, straight to curved, unistratose, not fragile, does not break easily when dissecting; apex obtuse, mucronate; margins plane or incurved below, more incurved in the upper part, entire or slightly toothed in the third basal part, papillose-crenulate above; costa mostly greenish, rarely red, gradually narrowing from mid-leaf to apex, (65-)80-100(-140) $\mu \mathrm{m}$ wide at base, excurrent in a mucro, 25-60 $\mu \mathrm{m}$ long, plane-convex in cross-section with two well developed stereid bands, up to 6 guide cells in the basal part and 3-4 in the upper part, one row of ventral cells and one row of dorsal cells, dorsal side of costa slightly to coarsely papillose to the apex; laminal cells mid-basal and paracostals long-rectangular and thin-walled, marginal basal cells longer and narrower, with 1-2 rows ascending the lamina and exceeding the transitional papillose cell area, upper cells quadrate to shortly rectangular, 5.0-8.0 x 5.0-8.0 $\mu \mathrm{m}$, opaque, with several bifurcate blunt papillae, more developed on the ventral side, marginal cells in the median and upper part not differentiated; dioicous; perigonia subapical; perigonial leaves similar to vegetative leaves but smaller; perichaetia apical; perichaetial leaves usually similar to vegetative leaves, occasionally heteromorphic, with one leaf narrower and longer than the other, or sometimes smaller; seta 5-10 mm long, yellowish; capsule ellipsoidal to cylindrical, yellow-reddish to brownish, $1.00-1.50 \times 0.35-0.60 \mathrm{~mm}$; operculum long-conical to rostrate, erect or inclined, $0.60-0.70 \mathrm{~mm}$ long; annulus persistent, formed by 3-5 rows of quadrate, thick-walled, reddish cells; peristome absent to rudimentary formed by a short papillose basal membrane or by small segments arising from basal membrane, not exceeding the mouth of the urn, bifurcate, perforate, hyaline to pale orange, papillose, up to $55 \mu \mathrm{m}$ long; spores $14-20 \mu \mathrm{m}$, densely and irregularly warty.

Distribution and habitat - Of the four species, T. meridionale clearly occupies the narrowest distribution and ecological niche. Its known range includes Macaronesia (Canary Islands) and on the shores of the Mediterranean including Corsica, Italy (Tuscany) and Sardinia [5]. Trichostomum brachydontium var. densum is reported in southern Europe [41], and more precisely Baleareic Islands and Spain [6,7]. The present study has confirmed its presence in southern Spain (Alicante, Almería and Murcia provinces), Greece (Eastern Aegean Islands) and Sardinia. It is more or less confined to open coastal scrubland, including phrygana and garigue, on relatively alkaline and calcarous soils in the Mediterranean bioclimatic zone. The material studied shows an elevational range from sea-level to $650 \mathrm{~m}$ (Spain). 


\subsection{Key to species}

1a. Plants very small, $0.3-0.5(-1.0) \mathrm{cm}$ tall, growing in dense short turfs; leaves lingulate, narrowly elliptical, spathulate to panduriform, with an obtuse apex ending in a short mucro, 25-60 $\mu \mathrm{m}$ long; costa strong, gradually narrowing from mid-leaf to apex; sporophyte often present, seta 5-10 mm long, urn 1.0-1.5 mm long, peristome absent or rudimentary up to $\quad 55 \quad \mu m$

\section{T. meridionale}

1b. Plants larger, (1.0-)2.0-3.0(-5.0) cm tall, growing in tufts or cushions; leaves lingulate, oblong-lingulate, lanceolate, ensiform or linear-lanceolate, with an obtuse, acute, short-acuminate or long-acuminate apex ending in a short or long mucro; costa gradually narrowing from base to apex; sporophyte if present, seta (5-)10-20 mm long, urn 1.2-2.2 $\mathrm{mm}$ long, peristome rudimentary or well developed up to $250 \mu \mathrm{m}$ long

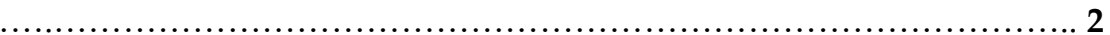

2a. Margins at the base of leaf lamina (transitional zone to papillose cells) usually with prominent teeth; leaves broadly lingulate, oblong-lingulate, slightly lanceolate or spatulate, up to $1.90(-2.30) \mathrm{mm}$ long, 3.0-4.6(-6.6) times as long as wide, apex obtuse; costa excurrent in a mucro $20-85 \quad \mu m$ long .................................................................... littorale

2.b. Margins at the base of leaf lamina entire or with weakly developed teeth; leaves narrowly lingulate, narrowly lanceolate, ensiform or linear-lanceolate, up to 3.45(-3.61) $\mathrm{mm}$ long, 5.0-8.9 times as long as wide, apex short- or long-acuminate to subulate, more rarely acute; costa excurrent in an arista (50-)70-150 $\mu \mathrm{m}$ long ... 3

3a. Plants reddish colour below apex; leaves linear-lanceolate, strongly canaliculate, not twisted, undulate or not, not fragile, basal lamina reddish, concolorous with upper lamina; mid-basal and paracostal basal cells usually thick-walled, obscurely nodulose; sporophyte rarely present T. herzogii

3.b. Plants brown colour below apex; leaves narrowly lingulate to narrowly lanceolate or ensiform, flat to slightly canaliculate, twisted, undulate, fragile, basal lamina yellowish or hyaline, contrasting with upper lamina; mid-basal and paracostal basal cells thin-walled; sporophyte often present T. brachydontium

Author Contributions: Conceptualization, R.D.P., R.M.R. and O.W.; methodology, R.M.R., O.W. and R.D.P.; field research, R.D.P., R.M.R. and O.W.; molecular analysis, O.W.; morphological study, R.D.P. and R.M.R., writing - original draft preparation, R.M.R., R.D.P. and O.W.; writing-review and editing, R.D.P., R.M.R. and O.W.; funding acquisition, R.M.R. and O.W. All authors have read and agreed to the published version of the manuscript.

Funding: Field sampling in SE Spain was funded by Fundación Séneca-Agencia de Ciencia y Tecnología de la Región de Murcia, grant number 20785/PI/18.

Data Availability Statement: DNA sequences are available on the GenBank database and all authors agree with MDPI Research Data Policies.

Acknowledgments: We are especially grateful to T.L. Blockeel, N.G Hodgetts, D. Callaghan, M. Aleffi, V. Hugonnot, C. Sérgio and A. Cogoni for undertaking field collecting and providing material for the study. We thank J. Muñoz for his invaluable help in relation to nomenclature and study of types and providing literature, and V. Mazimpaka for his help with botanical Latin. Many thanks also to S. Fernández and A. Werner for their help in preparing the photographic plates. Curators of the following herbaria gave their time in searching for types in AUT, BM, BR, DR G, LY, LYJB and we wish to acknowledge GLM, GOET, H, JE and NY for the loan of type specimens. 
Conflicts of Interest: The authors declare no conflict of interest.

\section{Appendix A}

Sampled taxa with voucher information and GenBank accession numbers for both or any of the sequenced markers. If sequence is already published, literature reference is given. Non-sequenced specimens are also indicated.
Code (Haplo-
Locality (Voucher)
GenBank Accession Numbers

type)

ITS / $r b c L$

Trichostomum brachydontium s.s.

SPAIN, Andalusia, Cádiz, Los Barrios, Sierra de Ojén, Canuto del

AY796252 [21] /-

Cebrillo, 28.12.1999, J. Guerra E R.M. Ros s.n., MUB 12650

PORTUGAL, Algarve, Serra de Monchique, Vale de Cova da

TO BE ADDED

Serra, 17.05.2020, R.D. Porley s.n., Herb. Porley, duplicate MUB 60458.

PORTUGAL, Algarve, Serra de Monchique, Barranco Parral

TO BE ADDED

North, 06.04.2014, R.D. Porley s.n., Herb. Porley, duplicate MUB

$$
60459
$$

GREECE, Cyclades, Andros, Frousei, near Palestou, ca. 240 m, 19.03.2016, T.L. Blockeel 45/085, Herb. Blockeel, duplicate MUB

\section{0}

GREECE, Cyclades, Andros, above Arnim near Vourkoti, ca. 670 m, 19.03.2016, T.L. Blockeel 45/129, Herb. Blockeel, duplicate MUB 60461.

ITALY, Sardinia, prope Cagliari, Feb. 1827, Müller, JE 04008873 (Lectotype of T. brachydontium).

ITALY, Sardinia, prope Cagliari, Feb. 1827, Müller, JE 04008874 (Syntype of T. brachydontium).

ITALY, Toscana, Firenze, Giardino di Boboli, 29.03.1988, C. Cortini

$$
\text { s.n., CAME }
$$

ITALY, Toscana, Alpi Apuane, lungo il torrente Renara fra Guadine e Casania (Massa), 20.11.1988, C. Cortini \& M. Aleffi s.n.,

\section{CAME}

ITALY, Toscana, Alpi Apuane, Desiate (Riomagno), 19.11.1988, C. Cortini \& M. Aleffi s.n., CAME

ITALY, Sardinia, Chia, Domus de Maria, 07.04.2006, A. Cogoni s.n.,

$$
\text { CAG }
$$

ITALY, Sardinia, Rio Santa Lucia, Assemini, 01.10.2020, A. Cogoni s.n., CAG

ITALY, Sardinia, Is Pauceris, Assemini, 25.05.2021, A. Cogoni s.n., CAG (var. cylindricum)

MOROCCO, Bab Taza, ascensión al Jbel Bouhalla, El Maounzil, $35^{\circ} 04^{\prime} 45^{\prime \prime} \mathrm{N}, 5^{\circ} 10^{\prime} 05^{\prime \prime} \mathrm{W}, 1100 \mathrm{~m}, 17.03 .1997$, M.J. Cano, M.T. Gallego E R.M. Ros s.n. MUB 10961

PORTUGAL, Algarve, Serra de Monchique, Ribeira de Seixoso, 07.01.2010, R.D. Porley s.n., Herb. Porley, duplicate MUB 60462 PORTUGAL, Algarve, Serra de Monchique, Carrapateira, Costa Vicentina PN, 27.21.2007, R.D. Porley s.n., Herb. Porley, duplicate

\section{MUB 60463}

PORTUGAL, Algarve, Serra de Monchique, Ribeira do Seixoso, 07.01.2010, R.D. Porley 31, Herb. Porley, duplicate MUB 60464

PORTUGAL, Algarve, Serra de Monchique, Ribeira do Seixoso, 07.01.2010, R.D. Porley 32, Herb. Porley, duplicate MUB 60465 
PORTUGAL, Algarve, Serra de Monchique, Ribeira do Seixoso, 07.01.2010, R.D. Porley 34, Herb. Porley, duplicate MUB 60467 PORTUGAL, Algarve, Serra de Monchique, Ribeira do Seixoso, 05.02.2010, R.D. Porley 35, Herb. Porley, duplicate MUB 60468 PORTUGAL, Algarve, Serra de Monchique, Ribeira do Seixoso, 07.01.2010, R.D. Porley 36, Herb. Porley, duplicate MUB 60469

PORTUGAL, Algarve, Serra de Monchique, Ribeira de Boina, S. of Brejão, 22.12.2010, R.D. Porley 37, Herb. Porley, duplicate MUB 60470

PORTUGAL, Algarve, Serra de Monchique, Ribeira do Seixoso, 18.01.2010, R.D. Porley 45, Herb. Porley, duplicate MUB 60471 PORTUGAL, Algarve, Monte do Galo, near Cerca dos Pomares, 12.11.2021, R.D. Porley s.n., Herb. Porley

PORTUGAL, Madeira, S. Vicente, Folhadal, entre o $1^{\mathrm{o}}$ e $2^{\mathrm{o}}$ Tunel a partir da Encumeada, 29.02.1982, M. Pita 5, LISU1492332

PORTUGAL, Madeira, Ribeiro Frio, 12.05.1979, C. Sérgio 2365, LISU162400

PORTUGAL, Madeira, Faldas do Pico Jorge, Levada para a Ribeiro Bonito,12.04.1988, C. Sérgio E M. Nóbrega 6132, LISU162405 PORTUGAL, Madeira, Fanal de Baixo, Riberia Funda descendo para a Ribeira, 28.06.1988, C. Sérgio \& M. Nóbrega 6132, LISU162406 SPAIN, Balearic Islands, Mallorca, cruce de Carretera Sacalobra y carretera a Pollensa, cerca del chiringuito, 394ㅇ' $05^{\prime \prime} \mathrm{N}, 2^{\circ} 49^{\prime} 05^{\prime \prime} \mathrm{E}$, 580 m, 16.04.1999, M.J. Cano, M.T. Gallego E M.C Sánchez-Moya,

\section{MUB 11128}

SPAIN, Canary Islands, Tenerife, Anaga, Junto a Puente, 29.10.2003. R.M. Ros, A. Losada E J.M. González-Mancebo, MUB 16625

GREAT BRITAIN, England, N. Somerset, Walton-in-Gordano, 31.01.1989, R.D. Porley 1392, Herb. Porley

GREAT BRITAIN, Wales, Montgomeryshire, Guilsfield, 02.07.1978, M.J. Wigginton s.n., Herb. Porley

\section{Trichostomum herzogii} near Cressbrook, 30.04.2021, T.L. Blockeel 50/064, Herb. Blockeel,

$$
\text { duplicate MUB } 60473
$$

3300 FRANCE, Ain, Lélex, Pont du Rouffes, 01.07.2020, V. Hugonnot s.n., Herb. Hugonnot, duplicates Herb. Porley, MUB 60457

FRANCE, prope Aix en Provence, 30.06.1874, Philibert, HA.H3400241 (sub Hymenostomum unguiculatum)

GERMANY, auf Kalkfelsen des Hohensteins bei Warburg (collector unknown s.n., s.d.) Lectotype, JE04008876 (Lectotype of Trichostomum cuspidatum)

GERMANY, am Massenkalkfels des Hohenstein bei Warstein (s.d.)

H. Müller, JE04008877 (Isotype of Trichostomum cuspidatum)

GERMANY, Warstein, H. Müller (s.d.) JE04008878 (Isotype of Trichostomum cuspidatum)

GERMANY, in Klüften der Massenkalkfelsen im Lürmekethal [Lörmecketal] u. am Hohen Stein bei Warstein im Sauerland u. bei 
GREAT BRITAIN, Wales, Breconshire, Craig Cerrig Gleisand

NNR, 950 m, R.D. Porley 1470, Herb. Porley

GREAT BRITAIN, England, Shropshire, Alberbury, R.D. Porley

1391, Herb. Porley

ITALY, Toscana, Afuane, Can. del Rio, 680 m, 27.07.1990. M. Aleffi,

CAME

\section{Trichostomum littorale}

GREAT BRITAIN, Cornwall, Kynance Cove, Lizard, 13.02.2011, J.A. Norton 130211, Herb. D. Callaghan, duplicate MUB 60475

3213 GREAT BRITAIN, Shetland Islands, Eshaness, 31.08.2014, S.V.O' Leary s.n., Herb. D. Callaghan 310814, duplicate MUB 60476

3232 PORTUGAL, Algarve, Serra de Monchique, Barbelote amphitheatre, $527 \mathrm{~m}, 27.10 .2016$, R.D. Porley 03, Herb. R. Porley, duplicate

\section{MUB 60477}

PORTUGAL, Algarve, Serra de Monchique, Picota, 737 n, 02.03.2017, R.D. Porley 04, Herb. Porley, duplicate MUB 60478 cate MUB 60479

PORTUGAL, Algarve, Serra de Monchique, Chilrão, 480 m, 30.07.2015, R. Porley 10, Herb. Porley, duplicate MUB 60480 raco, 740 m, 06.02.2015, R.D. Porley 11, Herb. Porley, duplicate

\section{MUB 60481}

PORTUGAL, Algarve, Serra de Monchique, Ribeira da Cerca, W. of Marmelete, 19.08.2015, R.D. Porley 41, Herb. Porley, duplicate

\section{MUB 60482}

11187, Herb. N.G. Hodgetts, duplicates Herb. Porley, MUB 60484

IRELAND, County Kerry, Torc, Muckross Lake, N.G. Hodgetts

11181, Herb. Hodgetts, duplicates Herb. Porley, MUB 60485 IRELAND, NY 01449062 (Lectotype)

GREAT BRITAIN, Whitsand Bay Cornwall, F. Brent, 0 3.02.1868, NY 01449063 (Syntype)

GREAT BRITAIN, a little East of Fairlight Down near Hastings, Sussex, July 1847, W.M., NY 01449064 (Syntype)

ITALY, Prov. La Spezia, Bachschlucht ca. $1 \mathrm{~km}$ vor Pignone an der Str. nach La Spezia im Castanea-Wald, 25.03.1965, R. Düll s.n., CAME.

PORTUGAL, Algarve, Serra de Monchique, Barbelote amphitheatre, 600 m, 02.04.2015, R.D. Porley 02, Herb. Porley, duplicate MUB 60486

PORTUGAL, Algarve, Serra de Monchique, Ribeira de Seixoso, 125 m, 05.02.2010, R.D. Porley 07, Herb. Porley, duplicate MUB 60487

PORTUGAL, Algarve, Serra de Monchique, Ribeira de Seixoso, 125 m, 05.02.2010, R.D. Porley 09, Herb. Porley, duplicate MUB 60488

PORTUGAL, Algarve, Serra de Monchique, Fóia, north side, 815 m, 03.12.2015, R.D. Porley 12, Herb. Porley, duplicate MUB 60489 
PORTUGAL, Algarve, Serra de Monchique, Fóia, Penado do Buraco, 05.02.2015, R.D. Porley 24, Herb. Porley

PORTUGAL, Algarve, Serra de Monchique, Chilrão, 500 m, 28.02.2014, R.D. Porley 29, Herb. Porley

PORTUGAL, Algarve, Serra de Monchique, Ribeira do Seixoso, 125 m, 05.02.2010, R.D. Porley 30, Herb. Porley

PORTUGAL, Algarve, Ribeira da Cerca, Cerca dos Pomares, 50 m, 26.06.2013, R.D. Porley 39, Herb. Porley

PORTUGAL, Algarve, Serra de Monchique, Ribeira da Cerca, W. of Marmelete, 180 m, 19.08.2020, R.D. Porley 40, Herb. Porley

PORTUGAL, Algarve, Serra de Monchique, Ribeira da Cerca, W. of Marmelete, 163 m, 05.08.2020, R.D. Porley 43, Herb. Porley

SPAIN, Andalusia, Cádiz, Medina-Sidonia, Sierra Blanquilla, arroyo del Alisoso, 16.04.2000, J. Guerra s.n., MUB 11257

GREAT BRITAIN, Scotland, Outer Hebrides, Clash na Bearnaich,

Hirta, St. Kilda, 100 m, 09.07.2013, R.D. Porley s.n., Herb. Porley

GREAT BRITAIN, Scotland, Orkney, Egilsay, 6 m, 12.07.2006, R.D. Porley 2917, Herb. Porley

GREAT BRITAIN, England, North Devon, Bideford Bay, Saunton, 8 m, 05.08.2003, R.D. Porley 2644, Herb. Porley

Trichostomum meridionale

SPAIN, Murcia Region, Bullas, Salto Lucero, 650 m, 20.11.2002, R.M. Ros s.n., MUB 14240 (Paratype)

TO BE ADDED

GREECE, Eastern Aegean Islands, Rhodes, ca $1.2 \mathrm{~km}$ SE of Moni

TO BE ADDED

Artamiti, ca, 240 m, 08.03.2018, T.L. Blockeel 47/027, Herb. Blockeel, duplicate MUB 60472 (Paratype)

3259 SPAIN, Murcia Region, Sierra Minera de Cartagena-La Unión, Rambla del Gorguel, 131 m, 04.03.2020, R.M. Ros, O. Werner E P. Egea Benavente s.n., MUB 60287, duplicate Herb. Porley (Paratype) SPAIN, Murcia Region, Cartagena, Atamaría, camino que sube al Monte de las Cenizas, en la carretera RM-514, 151 m, 04.03.2020,

DNA 3260, R.M. Ros, O. Werner E P. Egea Benavente s.n., MUB 60288, duplicate Herb. Porley (Paratype)

SPAIN, Murcia Region, Cartagena, Atamaría, camino que sube al Monte de las Cenizas, en la carretera RM-514, 151 m, 04.03.2020,

DNA 3261, R.M. Ros, O. Werner E P. Egea Benavente s.n., MUB 60289, duplicate Herb. Porley (Paratype)

SPAIN, Murcia Region, Cartagena, Calarreona, 0 m, 04.03.2020,

DNA 3262, R.M. Ros, O. Werner \& P. Egea Benavente s.n., MUB 60290, duplicate Herb. Porley (Paratype)

SPAIN, Murcia Region, Cartagena, Calarreona, 0 m, 04.03.2020,

DNA 3263, R.M. Ros, O. Werner E P. Egea Benavente s.n., MUB 60291, duplicate Herb. Porley (Paratype)

3264 SPAIN, Murcia Region, Las Torres de Cotillas, Urbanización Los

Romeros, calle I, parcela en la zona más alta, 144 m, 07.03.2020,

R.M. Ros s.n., MUB 60293 (Paratype)

3265 SPAIN, Murcia Region, Las Torres de Cotillas, Urbanización Los

Romeros, calle I, parcela en la zona más alta, 144 m, 02.05.2020,

R.M. Ros s.n., MUB 60296, duplicate Herb. Porley (Paratype)

3266 SPAIN, Murcia Region, Murcia, Rambla del Puerto de La Cadena, 260 m, 26.03.2019, R.M. Ros E M. Farag s.n., MUB 60292, duplicate

TO BE ADDED

TO BE ADDED

TO BE ADDED

TO BE ADDED

TO BE ADDED

TO BE ADDED

TO BE ADDED

TO BE ADDED 
3268 SPAIN, Murcia Region, Murcia, El Valle Perdido, proximidades a

TO BE ADDED

Santuario de la Fuensanta, 143 m, 14.03.2020, R.M. Ros E O. Werner s.n., MUB 60295, duplicate Herb. Porley (Holotype)

3269 SPAIN, Murcia Region, Murcia, El Valle Perdido, proximidades a

TO BE ADDED Santuario de la Fuensanta, 143 n, 14.03.2020, R.M. Ros E O. Werner s.n., MUB 60294, duplicate Herb. Porley (Paratype)

3270 SPAIN, Murcia Region, Cartagena, Punta de la Azohía, 50 m, 06.03.2009, R.M. Ros s.n., MUB 29467, duplicate Herb. Porley (Paratype)

ITALY, Sardinia, S. Elia, Cagliari, pianoro per Cala Fighera, 17.05.2001, A. Cogoni s.n., CAG

ITALY, Sardinia, Casa Laura, Giara di Gesturi, Genoni, 08.03.2002, A. Cogoni s.n., CAG (sample with intermediate characters with $T$. littorale)

SPAIN, Alicante, Cabo de la Nao, (Jávea), M.J. Cano s.n, MUB 5565 SPAIN, Almería, camino a Río de Aguas desde El Cerrón (Sorbas), 18.03.1988, J.J. Martínez-Sánchez, R.M. Ros E J. Guerra s.n., MUB 6101

Trichostomum sp.

2178 AUSTRIA, Styria, Hochschwab massif, Pfarrerlacke W of Tragöss, TO BE ADDED ca 930 m, 06.10.2006, H. Köckinger 12338, Herb. Köckinger, duplicates Herb. Porley, MUB 60490 27.03.2019, T.L. Blockeel 48/098, Herb. Blockeel, duplicates Herb. Porley, MUB 60491

\section{Trichostomum crispulum}

PORTUGAL, Algarve, Senhora da Rocha, Lagoa, 17.03.2013, R.D. Porley 16, Herb. Porley, duplicate MUB 60492 SPAIN, Galicia, Orense, Monasterio de San Estevo de Ribas de Sil, 20.08.2021, R.M. Ros E A. Werner Ros s.n., MUB 60493 SPAIN, Andalusia, Jaén, Sierras del Sur de Jaén, carretera hacia Monumento Natural Quejigo del Carbón o del Amo, 04.05.2021, R.M. Ros E O. Werner s.n., MUB 60494

\section{Outgroup specimens}

Barbula unguiculata 3203

Oxystegus sp.

Oxystegus tenuirostris

Tortella alpicola

Tortella flavovirens
GREAT BRITAIN, Durslton Head, Dorset, A. Norton 81213, Herb. Callaghan, duplicate MUB 60495

MALAWI, Zomba plateau, peak road below Malumbe Peak, D. Long 12608, BM

AUSTRIA, Styria, Stubalpe, Granitzgraben SE of Weisskirchen, H. Köckinger 14245a, GZU, MUB 31054 SPAIN, Sierra Nevada, Collado de La Mosca, S. Rams s.n., MUB 21926 GREECE, Pelopónnisos, M.J. Cano et al. s.n., MUB 11940
TO BE ADDED

TO BE ADDED

TO BE ADDED

TO BE ADDED

AY854390 [21,24] /-

HM049797 [24] /-

HM049809 [24] /-

AY796262 [21] /- 


\begin{tabular}{|c|c|c|}
\hline Tortella flavovirens 3255 & $\begin{array}{c}\text { PORTUGAL, Algarve, Serra de Monchique, Gralhos, } \\
\text { Via Alagarviana, } 545 \text { m, 26.01.2018, R.D. Porley 26, } \\
\text { Herb. Porley }\end{array}$ & - / TO BE ADDED \\
\hline Tortella inclinata 3247 & $\begin{array}{c}\text { PORTUGAL, Algarve, Serra de Monchique, Penedo } \\
\text { do Buraco waterfall, } 655 \text { m, 01.02.2016, R.D. Porley 18, } \\
\text { Herb. Porley }\end{array}$ & - / TO BE ADDED \\
\hline Tortella humilis & SPAIN, Albacete, R.M. Ros \& O. Werner s.n.,MUB 17767 & AY796260 [21]/- \\
\hline Tortella squarrosa & $\begin{array}{c}\text { CZECH REPUBLIC, Tmaň-Kotýz, J. Košnar 1266, CBFS } \\
562\end{array}$ & JX679950 [53] /- \\
\hline Tortella tortuosa & MOROCCO, Rif, M.J. Cano \& R.M. Ros, s.n., MUB 10397 & AY796266 [21]/- \\
\hline
\end{tabular}

\section{References}

1. Blockeel, T.L. Trichostomum brachydontium. In: Atlas of British E Irish bryophytes; Blockeel, T.L., Bosanquet, S.D., Hill, M.O., Preston, C.D. Eds.; Pisces Publications: Newbury, UK, 2014; p. 141. ISBN 978-1-874357-62-9.

2. Zander, R.H. Trichostomum. In Flora of North America North of Mexico, Vol. 27, Flora of North America Editorial Committee, Ed.; Oxford University Press: New York, USA, 2007; pp. 488-494.

3. Guerra, J. Trichostomum Bruch. In Flora Briofítica Ibérica, Vol. 3; Guerra, J., Cano, M.J., Ros, R.M. Eds.; Universidad de Murcia y Sociedad Española de Briología: Murcia, Spain, 2006; pp. 76-83.

4. Müller, F.A. Erstes Verzeichnis sardinischer Laubmoose, wie auch derjenigen welche von meinen Freunde Herrn Fleischer bei Smyrna aufgefunden worden sind, nebst Beschreibungen und Abbildungen einiger neuen Arten. Flora 1829, 12, 385-399.

5. Herzog, T. Studien über den Formenkreis des Trichostomum mutabile Br. Abhandlungen der Kaiserlich LeopoldinischCarolinische Deutsche Akademie der Naturforscher, Nova Acta 1907, 73, 453-481.

6. Rungby, S. A Contribution to the Bryophytic Flora of Spain and Morocco, Especially the Area between Gandía and Alcoy. Botaniska Notiser 1962, 115, 61-64.

7. Koppe, F. Bryologische Beobachtungen auf der Insel Mallorca. Botaniska Notiser, 1965, 118, $25-48$.

8. Renauld, F.; Cardot, J. Mousses des Canaries. M. Albert Tullgren et coup d'oeil sur la flore bryologique des îles atlantiques. Bulletin de l'Herbier Boissier, sér. 2, 1902, 2, 433-453.

9. Sérgio, C. Acerca da identidade de Hyophila contorta (Kunze) Jaeg. Pottiaceae da Ilha da Madeira. Portugaliae Acta Biologica, Série B, Sistemática, Ecologia, Biogeografia e Paleontologia 1985, 14, 168-172.

10. Sérgio, C.; Sim-Sim, M; Carvalho, M. Annotated catalogue of Madeiran bryophytes. Boletim do Museu Municipal do Funchal (Historia Natural) Suplemento 2006, 10, 5-163.

11. Hill, M.O.; Bell, N.; Bruggeman-Nannenga, M.A.; Brugués, M.; Cano, M.J.; Enroth, J.; Flatberg, K.; Frahm, J.-P.; Gallego, M.; Garilleti, R.; Guerra, J.; Hedenäs, L.; Holyoak, D.T.; Hyvönen, J.; Ignatov, M.S.; Lara, F.; Mazimpaka, V.; Muñoz, J.; Söderström, L. An annotated checklist of the mosses of Europe and Macaronesia. Journal of Bryology 2006, 28, 198-267.

12. Ros, R.M.; Mazimpaka, V.; Abou-salama, U.; Aleffi, M.; Blockeel, T.L.; Brugués, M.; Cros, R.M.; Dia, M.G.; Dirkse, G.M.; Draper I.; El-Saadawi, W.; Erdağ, A.; Ganeva, A.; Gabriel, R.; González-Mancebo, J.M.; Granger, C.; Herrnstadt, I.; Hugonnot, V.; Khalil, K.; Kürschner, H.; Losada-Lima, A.; Luís, L.; Mifsud, S.; Privitera, M.; Puglisi, M.; Sabovljević, M.; Sérgio, C.; Shabbara, H.; Sim-Sim, M.; Sotiaux, A.; Tacchi, R.; Vanderpoorten, A.; Werner, O. Mosses of the Mediterranean, an annotated checklist. Cryptogamie, Bryologie 2013, 34, 99-283.

13. Hodgetts, N.G.; Söderström, L.; Blockeel, T.L.; Caspari, S.; Ignatov, M.S.; Konstantinova, N.A.; Lockhart, N.; Papp, B.; Schröck, C.; Sim-Sim, M.; et al. An annotated checklist of bryophytes of Europe, Macaronesia and Cyprus. Journal of Bryology 2020, 42, 1-116.

14. Braithwaite, R. The British Moss-Flora Vol. 1. Acrocarpi 1.; L. Reeve \& Co.: London: UK, 1887; pp. 1-315.

15. Dixon, H.N.; Jameson, H.G. The Student's Handbook of British Mosses, 1st ed.; V. T. Sumfield: Eastbourne, UK, 1896; pp. 1-582.

16. Dixon, H.N. The Student's Handbook of British Mosses, reprint 3rd ed.; V.V. Sumfield: Eastbourne, UK, 1924; pp. XLVI +1-586. 
17. Smith A.J.E. The moss flora of Britain and Ireland. Cambridge University Press: Cambridge, UK, 1978; pp. VIII + 1706.

18. Smith, A.J.E. The moss flora of Britain and Ireland, 2nd ed.; Cambridge University Press: Cambridge, UK, 2004; pp. XII + 1-1012.

19. Renner, M.A.M. Opportunities and challenges presented by cryptic bryophyte species. Telopea 2020, $23,41-60$.

20. Werner, O.; Ros, R.M.; Cano M. J.; Guerra, J. Molecular phylogeny of Pottiaceae (Musci) based on chloroplast rps4 sequence data. Plant Systematics and Evolution 2004, 243, 147-164.

21. Werner, O.; Ros, R.M.; Grundmann, M. 2005. Molecular phylogeny of Trichostomoideae (Pottiaceae, Bryophyta) based on nr ITS sequence data. Taxon 2005, 54, 361-368.

22. Werner, O.; Köckinger H.; Magdy, M.; \& Ros, R.M. On the systematic position of Tortella arctica and Trichostomum arcticum (Bryophyta, Pottiaceae). Nova Hedwigia 2014, 98, 273-293.

23. Ros, R.M.; Werner, O. The circumscription of the genus Pottiopsis (Pottiaceae, Bryophyta) based on morphology and molecular sequence data. Nova Hedwigia, Beiheft 2007, 131, 65-79.

24. Köckinger H.; Werner, O.; Ros, R.M. A new taxonomic approach to the genus Oxystegus (Pottiaceae, Bryophyta) in Europe based on molecular data. Nova Hedwigia, 2010, 138, 31-49.

25. Köckinger H.; Lüth M.; Werner O.; Ros R.M. Tortella mediterranea (Pottiaceae), a new species from southern Europe, its molecular affinities, and taxonomic notes on T. nitida. The Bryologist 2018, 121, 560-570.

26. Werner, O.; Ros, R.M.; Guerra, J. Direct amplification and $\mathrm{NaOH}$ extraction: two rapid and simple methods for preparing bryophyte DNA for polymerase chain reaction (PCR). Journal of Bryology 2002, 24, 127-131. doi: $\underline{10.1179 / 037366802125000980}$

27. White, T.J.; Bruns, T.; Lee, S.; Taylor, J. Amplification and direct sequencing of fungal ribosomal RNA genes for phylogenetics. In PCR protocols a guide to methods and applications; Innis, M.A., Gelfand, D.H., Sninsky, J.J. and White, T.J., Eds.; Academic Press: New York, USA, 1990; pp. 315-322.

28. Kress, W.J.; Erickson, D.L. A two-locus global DNA barcode for land plants: the cod-ing rbcL gene complements the non-coding trnH-psbA spacer region. PLoS One 2007, 2, e508 https://doi.org/10.1371/journal.pone.0000508

29. Kress, W.J.; Erickson, D.L.; Jones, F.A.; Swenson, N.G.; Perez, R.; Sanjur, O.; Bermingham, E.. Plant DNA barcodes and a community phylogeny of a tropical forest dynamics plot in Panama. Proceedings of the National Academy of Sciences of the United States of America 2009, 106, 18621-18626.

30. Hall, T.A. BioEdit: a user-friendly biological sequence alignment editor and analysis program for Windows 95/98/NT. Nucleic Acids Symposium Series 1999, 41, 95-98.

31. Kumar, S.; Stecher G.; Li M.; Knyaz C.; Tamura, K. MEGA X: Molecular Evolutionary Genetics Analysis across computing platforms. Molecular Biology and Evolution 2018, 35, 1547-1549.

32. Donath, A.; Stadler, P.F. Split-inducing indels in phylogenomic analysis. Algorithms for Molecular Biology 2018, 13, 12. doi:10.1186/s13015-018-0130-7

33. Notredame, C.; Higgins, D.G.; Heringa, J. T-Coffee. A Novel Method for Fast and Accurate Multiple Sequence Alignment. Journal of Molecular Biology 2000, 302, 205-217. doi:10.1006/jmbi.2000.4042

34. Huelsenbeck, J. P.; Ronquist, F. MrBayes: Bayesian inference of phylogeny. Bioinformatics 2001, 17, 754-755.

35. Ronquist, F.; Huelsenbeck, J. P. MrBayes 3: Bayesian phylogenetic inference under mixed models. Bioinformatics 2003, 19, 1572-1574.

36. Ronquist, F.; Teslenko, M.; van der Mark, P.; Ayres, D. L.; Darling, A.; Höhna, S., Larget, B.; Liu, L.; Suchard, M.A..; Huelsenbeck, J. P. MrBayes 3.2: Efficient Bayesian Phylogenetic Inference and Model Choice Across a Large Model Space. Systematic Biology 2012, 61, 539-542. http://doi.org/10.1093/sysbio/sys029

37. Huelsenbeck, J. P.; Larget, B.; Alfaro, M. E. Bayesian phylogenetic model selection using reversible jump Markov chain Monte Carlo. Molecular Biology and Evolution 2004, 21, 1123-1133. https://doi.org/10.1093/molbev/msh123

38. Stöver, B. C.; K. F. Müller. TreeGraph 2: Combining and visualizing evidence from different phylogenetic analyses. BMC Bioinformatics 2010, 11, 7.

39. Maddison, W.P. Gene Trees in Species Trees. Systematic Biology 1997, 46, 523 - 536.

40. Pampilo, P.; Nei, M. Relationships between gene trees and species trees. Molecular Biology and Evolution 1988, 5, 568-583.

41. Mönkemeyer, W. Die Laubmoose Europas, Andreales-Bryales. Akademische Verlagsgesellschaft: Leipzig, Germany, 1927, pp. 1-960.

42. Eckel, P.M. Re-evaluation of Tortella (Musci, Pottiaceae) in conterminous U.S.A. and Canada with a treatment of the European species Tortella nitida. Bulletin of the Buffalo Society of Natural Sciences 1998, 36, 117-191.

43. Husnot, P.T. Muscologia Gallica. Première partie - Acrocarpes. F. Savy, Libraire: Paris, France, 1884-1890; pp. 1-284. 
44. Schimper, W.P. Synopsis Muscorum Europaeorum, prämissa introductione de elementis bryologicis tractante, 2nd ed.; Schweizerbart: Stuttgart, Germany, 1876; pp. CXXIV 1-866.

45. Wörz, A. The "Botanische Reiseverein" A 19th-century joint stock company for the collecting of herbarium specimens. Huntia 2007, 13, 121-141.

46. Stafleu, F.A.; Cowan, R.S. Taxonomic literature. Volume III: Lh-O, 2nd ed.; Bohn, Scheltema \& Holkema Utrechtdr. W. Junk b.v.: The Hague, Netherlands, 1981; pp. 1-980.

47. Hodgetts, N.; Lockhart, N. Checklist and country status of European bryophytes - update 2020. Irish Wildlife Manuals, 123; National Parks and Wildlife Service: Dublin, Ireland, 2020; pp. 1-214.

48. Mitten, W. New or rare British mosses. Journal of Botany, British and Foreign 1868, 6, 97-99, pl. 77.

49. Herzog, T. Geographie der Moose, Gustav Fischer: Jena, Germany, 1926; pp. XI + 1-439.

50. Frey, W.; Frahm, J-P.; Fischer, E.; Lobin, W. The liverworts, Mosses and Ferns of Europe, English edition, revised and edited by T. L. Blockeel; Harley Books: Colchester, England, 2006; pp. XV + 1-512.

51. Cortes Latorre, C. Aportaciones a la Briología española (dos musgos nuevos para la Flora española). Anales del Instituto Botánico A. J. Cavanilles 1956, 13, 135-147.

52. Esteve Chueca, F.; Cortes Latorre, C. El estrato liquénico-muscinal de la durilignosa de la Sierra de Cartagena. Anales del Instituto Botánico A. J. Cavanilles 1956, 13, 121-128. 